\title{
Gold and uranium concentration by interaction of immiscible fluids (hydrothermal and hydrocarbon) in the Carbon Leader Reef, Witwatersrand Supergroup, South Africa
}

Sebastian H. J. Fuchs ${ }^{1,2^{*}}$, Dirk Schumann ${ }^{3}$, Anthony E. Williams-Jones ${ }^{1}$, Andrew J. Murray ${ }^{3}$, Martin Couillard $^{4}$, Ken Lagarec ${ }^{3}$, Michael W. Phaneuf ${ }^{3}$ and Hojatollah Vali ${ }^{5}$

${ }^{1}$ Department of Earth and Planetary Science, McGill University, 3450 University Street, Montreal, QC, H3A OE8, Canada

${ }^{2}$ GEOMAR - Helmholtz Centre for Ocean Research Kiel, Wischhofstrasse 1-3, 24148 Kiel, Germany (present address)

${ }^{3}$ Fibics Incorporated, 1431 Merivale Road, Lower Level, Suite 100, Ottawa, ON, K2E 0B9, Canada

${ }^{4}$ National Research Council Canada, 1200 Montreal Road, Ottawa ON, K1A 0R6, Canada

${ }^{5}$ Facility for Electron Microscopy Research, McGill University, 3640 University Street, Montreal, H3A 2B2, Canada

${ }^{*}$ Correspondence should be addressed to sfuchs@geomar.de

\begin{abstract}
High-resolution scanning- and transmission-electron microscopy of pyrobitumen-hosted uraninite reveal that uraninite grains are highly porous aggregates of uniformly sized nanocrystals, and that many of their pores are filled by native gold. These texturally late gold grains, in turn, contain small pores occupied by former oil droplets that were converted to pyrobitumen during burial and metamorphism. The pyrobitumen in the pores of the gold grains contains in situformed uraninite nanocrystals. Galena also occupies the pores of the uraninite aggregates. In addition, this study reveals the first occurrence of rare lanarkite that engulfs the galena in the pores of the uraninite.

On the basis of the nature of the uraninite and the filling of some of its pores with native gold, we propose a mineralization

model for the deposition of the uranium and gold in the Carbon Leader Reef that calls upon the interaction of oil and aqueous (hydrothermal) fluids to form microemulsions. According to this model, uraninite nanocrystals precipitated from uraniumbearing hydrocarbon liquids and flocculated to form porous, uraninite aggregates. These liquids interacted with auriferous hydrothermal fluids in the Carbon Leader Reef, leading to the formation of a microemulsion at the interface between the two fluids. Gold precipitated as native metal around droplets of the oil owing to a reduction in oxygen fugacity, which destabilized the bisulfide species responsible for gold dissolution. Commonly, this process went hand in hand with the flocculation of the uraninite nanocrystals, causing entrapment of
\end{abstract}


the native gold in the pores of the uraninite aggregates. The hydrocarbon liquid, which occurs as droplets in the gold and is the host to the uraninite aggregates, was transformed to pyrobitumen. As a result of this process, a thin pyrobitumen seam containing uraninite nanocrystals formed along the inner walls of the pores in the native gold. Lead introduced by the hydrocarbon liquid precipitated as galena. Interaction of the uraninite with hydrothermal fluids or radiolysis of the pore water facilitated the development of local zones of oxidation between galena and uraninite, which led to the crystallization of rare lanarkite.

Citation: Fuchs, S.H.J., Schumann, D., Williams-Jones, A.E., Murray, A.J., Couillard, M., Lagarec, K., Phaneuf, M.W., Vali, H., 2017. Gold and uranium concentration by interaction of immiscible fluids (hydrothermal and hydrocarbon) in the Carbon Leader Reef, Witwatersrand Supergroup, South Africa. Precambrian Research 293, 39-55. doi:10.1016/j.precamres.2017.03.007 


\section{Introduction}

Although the giant Mesoarchean gold-uranium deposits in the Witwatersrand basin have been the subject of intensive study for over 50 years, their genesis remains a matter of considerable debate, with opinion being generally divided over whether they are hydrothermally modified paleoplacers (Frimmel, 1997; Frimmel et al., 2005; Kirk et al., 2002; Minter et al., 1993; Pretorius, 1991; Robb and Meyer, 1991, 1995) or entirely hydrothermal in origin (Barnicoat et al., 1997; Law and Phillips, 2005; Phillips and Law, 1994; Phillips et al., 1997; Phillips and Myers, 1989; Phillips and Powell, 2011). Supporters of the former model have attributed the deposition of the gold and uranium to fluvial processes involving heavy mineral concentration (native gold and uraninite), and later local remobilization of the gold by hydrothermal fluids. The uraninite is assumed to represent the original placer because of its rounded habit and the poor solubility of $\mathrm{U}^{4+}$ under reducing conditions. In contrast, advocates of the hydrothermal model favor introduction of the gold and uranium as dissolved species by migrating, oxidizing hydrothermal fluids from beneath and outside the Witwatersrand basin (Barnicoat et al., 1997; Phillips and Law, 2000).

Recently, two new models have emerged to address the issue of the origin of gold, which, given the enormous size of the resource, is considered by many not to be satisfactorily explained by the existing models. According to Frimmel and Hennigh (2015), the source of the gold was a "huge reservoir of meteoric and shallow sea water". In their model, the gold in this reservoir was concentrated by oxidative precipitation on mats of cyanobacteria that first appeared at around $3 \mathrm{Ga}$, and were reworked into placer deposits ("reefs"), which preserve remnants of these microbial mats as carbon seams. In the other model Heinrich (2015) proposed that Archean volcanic eruptions released sulfurous gases and produced acid rain, which facilitated the dissolution of gold in the hinterland and its transport in river water. Microbial mats present in shallow lakes and pools are inferred to have triggered gold precipitation by destabilizing the dissolved gold species through reduction.

An important feature of the gold-uranium mineralization is its close association with carbon seams. Approximately $40 \%$ of the gold in the reefs (mineable units) is associated with carbon seams (Nagy, 1993) and most of the uranium occurs within carbon seams. As with other aspects of Witwatersrand geology, the origin of the carbon seams is controversial. Some investigators, notably the early ones, interpreted them to be remnants of algal (microbial) mats that formed during or shortly after sedimentation (Hallbauer, 1975, 1986; Hallbauer and van Warmelo, 1974; Mossman et al., 2008), whereas others have proposed that they represent the residues of hydrocarbon liquids (Drennan et al., 1999; Drennan and Robb, 2006; England et al., 2002; Fuchs et al., 2016; Gray et al., 1998; Phillips and Law, 2000). The association of the gold with carbons seams in the hydrothermal model and hydrothermal remobilization in the modified paleoplacer model is explained by the need of a 
reductant to destabilize the bisulfide complexes thought to be responsible for gold transport (Phillips and Law, 2000; Phillips and Powell, 2011; Robb and Meyer, 1995). A similar, although pre-burial explanation involving microbial mats, as mentioned above, has been proposed in the two recently published models. In contrast, the association of uraninite with carbon seams has been attributed by some to radiolytic polymerization of formerly liquid hydrocarbons by pre-existing detrital uraninite, which immobilized them as solids (Schidlowski, 1981). The recent discovery of nanocrystals of uraninite of uniform size (5 $-7 \mathrm{~nm}$ in length) and larger aggregates of uraninite nanocrystals in organic matter from the Carbon Leader Reef, however, has placed this interpretation in doubt (Fuchs et al., 2015). Observing that these aggregates of uraninite nanocrystals cannot have been detrital in origin and that hydrocarbon fluid inclusions occur in overgrowths on quartz (Dutkiewicz et al., 1998; England et al., 2002; Fuchs et al., 2016), Fuchs et al. (2015) proposed, instead, that liquid hydrocarbons dissolved detrital uraninite and transported it to sites of re-mineralization, where it deposited as a result of nanocrystal flocculation or direct precipitation. According to this interpretation, the liquid hydrocarbons were transformed into pyrobitumen. The ubiquitous presence of uraninite nanocrystals within pyrobitumen is also confirmed by a recent study of the trace element chemistry of pyrobitumen (Fuchs et al., 2016) that shows homogeneous distribution of uranium in the hydrocarbons. Significantly, the suite of trace elements that is strongly enriched in and diagnostic of detrital uraninite (e.g., Th, W and REE; see Depiné et al. (2013)) is also enriched in the uraninite nanocrystals, suggesting that detrital uraninite may be the source of uranium in pyrobitumen.

In the current study we provide an explanation for the intimate association of native gold, uraninite and hydrocarbons in the Carbon Leader Reef of the Witwatersrand Supergroup. We provide evidence for the interaction of two immiscible fluids, namely hydrothermal and hydrocarbon liquids, and the formation of micro-emulsions that led to the deposition of native gold from the hydrothermal liquid on droplets of hydrocarbon liquid and uraninite from the hydrocarbon liquid. In so doing, we make the case for extensive hydrothermal mobilization of the gold and hydrocarbon mobilization of the uranium, and propose a unifying mineralization model that satisfactorily explains the association of the two metals in the carbon seams of the Carbon Leader Reef.

\section{Geological Setting}

The Carbon Leader Reef, the focus of this study, is a member of the 3.09 to $2.71 \mathrm{Ga}, 7.5 \mathrm{~km}$ thick, suite of metamorphosed quartzites, shales and conglomerates making up the Witwatersrand Supergroup, which rests on the uraniferous siliciclastic Dominion Group (3074 $\pm 6 \mathrm{Ma})$ metasedimentary rocks in the central part of the Kaapvaal Craton, South Africa. These units overlie a granitoid-greenstone basement (Armstrong et al., 1991), and, in turn, are overlain by metavolcanic and metasedimentary 
rocks of the Ventersdorp Supergroup $(2714 \pm 8 \mathrm{Ma})$. The Witwatersrand Supergroup has been subdivided into the lower West Rand Group and the upper Central Rand Group, which hosts the major gold-producing and uranium-bearing reefs, including the Carbon Leader Reef. The latter is a pyrite-, gold- and uranium-bearing metaconglomerate, located in the lower part of the Central Rand Group, which has been dated at 2,840 Ma (Kositcin and Krapež, 2004). Compressive deformation related to the Limpopo Orogeny led to synsedimentary thrust and wrench faulting (Coward et al., 1995). Extrusion of the Ventersdorp Supergroup flood basalts, emplacement of the Bushveld Igneous Complex and the Vredefort meteorite impact, induced regional lower greenschist-facies metamorphism and intense circulation of hydrothermal fluids (Coward et al., 1995; Robb and Meyer, 1995).

\section{The Carbon Leader Reef}

The Carbon Leader Reef is one of the major producing reefs of the Witwatersrand goldfields (Phillips and Law, 2000), with a resource of 117.74 tonnes gold and 1452 tonnes $\mathrm{U}_{3} \mathrm{O}_{8}$, having average grades of $22.53 \mathrm{~g} / \mathrm{t}$ gold and $0.28 \mathrm{~kg} / \mathrm{t} \mathrm{U}_{3} \mathrm{O}_{8}$, respectively (AngloGoldAshanti, 2014) (Fig. 1). It is relatively thin ( $\sim 1 \mathrm{~m}$ thick), and contains several hydrocarbon seams in the lowermost few centimeters of the quartzpebble conglomerate that forms the base of the unit. The conglomerate grades upward into a metasandstone, which is overlain by a second conglomerate that grades upward into a second metasandstone. Both metaconglomerates contain economic concentrations of gold and uranium that are generally associated with hydrocarbons (Grové and Harris, 2010).

The pyrobitumen seams in the Carbon Leader Reef are parallel to the sedimentary layering of the host metaconglomerate, but locally transect the conglomerate, forming discordant veins. They are up to $1 \mathrm{~cm}$ thick and can be divided into: I) seams with nodular morphology; and II) massive, irregularly shaped seams that are locally fibrous. Seams with nodular morphology consist of tabular to "spindle-shaped" nodules of similar size that are stacked to build a thick seam, the interstices of which are filled by a variety authigenic minerals, including pyrophyllite, muscovite, quartz, pyrite, florencite(Ce), crandallite, monazite-(Ce), brannerite, xenotime-(Y) and native gold (Fuchs et al., 2014). The massive pyrobitumen seams have irregular shapes due to their subdivision by numerous small and large fractures that are commonly filled with pyrophyllite, quartz and gold. In general, the seams are surrounded by detrital minerals (e.g., zircon, quartz and pyrite pebbles), although, the interstices within them are generally devoid of these minerals. 


\section{Methodology}

\subsection{Sample preparation, scanning-electron microscope and electron-microprobe analysis}

Pyrobitumen-bearing samples were selected from the Carbon Leader Reef in the TauTona mine of the Carletonville goldfield for the purpose of this study (Fig. 1). The samples were prepared as polished epoxy mounts (25 $\mathrm{mm}$ in diameter) (Fig. 2a). The samples were imaged using a Carl Zeiss Sigma HD VP field-emission scanning-electron microscope (SEM) at Fibics Incorporated (Ottawa, Canada), and employed the novel large-area imaging software, ZEISS Atlas 5. The high-resolution, large-area SEM imaging provided by the ZEISS Atlas 5 software enabled the acquisition of multi-resolution image mosaics up to terabytes in size of entire geological samples. Single image tiles of the mosaics can be as large as one gigapixel in size. The zoom in and out capability, similar to that of the well-known application "Google Earth ${ }^{\mathrm{TM}}$ ", allowed for the detailed investigation of the mineralogy and texture of the entire sample surfaces.

The samples were imaged with an accelerating voltage of $14 \mathrm{kV}$ using the backscattered electron (BSE) detector, a working distance of $11.8 \mathrm{~mm}$, a $7 \mathrm{nA}$ beam current (120 $\mu \mathrm{m}$ aperture), a $1.0 \mu$ s dwell time, and a resolution of $45 \mathrm{~nm} /$ pixel. The image mosaic of the sample, which is shown in Fig. 2a, comprises 2893 images, with each image tile containing 6148 x 6148 pixels (field of view per image $276.7 \times 276.7 \mu \mathrm{m})$. Several regions of interest were also imaged at a resolution of $5 \mathrm{~nm} /$ pixel.

The principal purpose of acquiring the large area-image mosaics was to understand the mineralogy, the mineral associations, and textures of the entire sample as well as to identify potential targets for the extraction of focused ion-beam (FIB) foils for subsequent transmission electron microscopy (TEM).

Energy-dispersive spectroscopic (EDS) analyses and the mapping of selected areas on FIBgenerated TEM lamellae (see section 4.4) were carried out at Fibics Inc. on a Zeiss Crossbeam 540 SEM equipped with a Gemini 2 electron column, a Capella Gallium ion FIB column and an Oxford Instruments $\mathrm{X}-\mathrm{Max}^{\mathrm{N}} 80 \mathrm{~mm}^{2}$ energy-dispersive X-ray spectroscopy (EDS) detector, which was controlled using the Aztec 3.0 software. The operating conditions for the EDS analyses were a $20 \mathrm{kV}$ accelerating voltage and a $2 \mathrm{nA}$ probe current. The processing time parameter 5 was used, and 45 to $450 \mathrm{~s}$ were required for the acquisition of the EDS maps. The latter were generated without quantification, and provided qualitative color-coded images of the distribution of the elements present in the sample. Additional element distribution maps were acquired using a JEOL 8900 electron microprobe (EPMA) equipped with an EDS detector and five WDS detectors, at McGill University. The operating conditions were a $20 \mathrm{kV}$ acceleration voltage, a $15 \mathrm{nA}$ current and $<1 \mu \mathrm{m}$ beam size.

\subsection{Atlas 5 Browser-Based Viewer}

Once the large-area image mosaics acquired by the Zeiss Atlas 5 software had been stitched and corrected, the entire datasets were exported to an autonomous series of files called the Browser-based 
Viewer. This viewer is scripted in HTML and JavaScript code, and optimized by taking advantage of the pyramidal images concept, which allows a view of the complete dataset at full resolution using a web browser. Access and the capability to navigate through the large area image mosaic of the Carbon Leader Reef sample are provided at: http://www.petapixelproject.com/mosaics/Witwatersrand/CL-N6exported-BBV/CL-N6-overview/index.html

\subsection{TEM sample preparation and TEM analysis}

Three ultra-thin foils were prepared for TEM investigation using a FIB technique (Wirth, 2004, 2009). The $15 \times 8 \times 0,10 \mu \mathrm{m}$-sized slices were prepared using a FEI FIB 200 system at the Focused Ion Beam Laboratory of the German Research Centre for Geosciences (GFZ), Potsdam. After being cut, the FIB lamellae were extracted and placed on a perforated carbon film on a copper TEM grid.

A FEI Tecnai G ${ }^{2}$ F20 Cryo-S/TEM located in the Facility for Electron Microscopy Research (FEMR) at McGill University (Montréal, Canada) and a FEI Titan ${ }^{3}$ 80-300 S/TEM located at the National Research Council (Ottawa, Canada) were used to conduct bright-field imaging, high-angle annular dark-field (HAADF) imaging, electron energy-loss spectrometric (EELS) and energydispersive spectroscopic (EDS) analyses on the extracted FIB lamellae. The FEI Tecnai G ${ }^{2}$ F20 200kV Cryo-S/TEM is equipped with a Gatan Ultrascan 4000 4k x 4k CCD Camera System, Model 895, and EDAX Genesis EDS. The spherical aberration coefficient, Cs, of the TEM is $2.0 \mathrm{~mm}$, and the point-topoint resolution in bright-field mode is $0.27 \mathrm{~nm}$. The resolution in STEM HAADF mode is $0.24 \mathrm{~nm}$. The inner and outer limits of the collection angles of the Fischione HAADF detector (model 3000) were approximately $53 \mathrm{mrad}$ and $322 \mathrm{mrad}$. A $100 \mu \mathrm{m}$ condenser aperture was used for HAADF imaging. This technique provides a signal intensity related mainly to the atomic number $(Z)$ and the thickness of the region analyzed. The FEI Titan ${ }^{3} 80-300$ TEM operated at $300 \mathrm{keV}$, and was equipped with a CEOS aberration corrector for the probe-forming lens. A monochromated field-emission gun was used to simultaneously acquire bright-field and HAADF images. Bright-field images were acquired with a Gatan detector, and HAADF images were collected using a Fischione detector in scanning-transmission electron microscopy (STEM) mode. The convergence angle was set at $15 \mathrm{mrad}$, and the HAADF collection angle was set at $50 \mathrm{mrad}$. The microscope is also equipped with an energy dispersive X-ray (EDS) spectrometer (EDAX Analyzer, DPP-II) and an electron energy-loss spectrometer (EELS). The EELS analyses were performed on a Gatan Tridiem 866 Image Filter. The EELS collection angle was set at $30 \mathrm{mrad}$.

\subsection{D focused-ion beam (FIB-SEM) nanotomography}

High-resolution FIB-SEM nanotomography was conducted at Fibics Incorporated, Ottawa, Canada. The nanotomography was carried out on the same Zeiss Crossbeam 540 FE-SEM as described in section 4.1. All nanotomography runs used the Atlas 3D module of the "Atlas $5^{\text {TM" }}$ software, which allows interlaced milling and imaging. During site preparation, selected sites with excessive 
topography were flattened through the FIB deposition of a carbon layer. Deposition parameters of this carbon layer were as follows: FIB acceleration voltage of $30 \mathrm{kV}$, a beam current of $1.5 \mathrm{nA}$, a dose of 1.25 $\mathrm{nC} / \mu \mathrm{m}^{2}$ (Carbon), a dwell time of $0.2 \mu \mathrm{s}$, a horizontal dwell point spacing of $160 \mathrm{~nm}$ and vertical dwell point spacing of $107 \mathrm{~nm}$, and a nominal spot size of $107 \mathrm{~nm}$. For the ATLAS 3D preparation of the uraninite aggregate, an initial tungsten protection layer was deposited into which tracking notches were patterned.

The automated FIB milling of the uraninite aggregate was carried out with the $\mathrm{Ga}^{+}$FIB at an acceleration voltage of $30 \mathrm{kV}$, a beam current of $300 \mathrm{pA}$, a dose of $30 \mathrm{nC} / \mu \mathrm{m}^{2}$, a dwell time of $0.3 \mu \mathrm{s}$, a slice thickness of $5 \mathrm{~nm}$, and a spot size of $35 \mathrm{~nm}$. The automated SEM image acquisition was carried out with the InLens detector at an acceleration voltage of $3 \mathrm{kV}$, with a $30 \mu \mathrm{m}$ aperture, a resolution of 5 $\mathrm{nm} /$ pixel, and a dwell time of $1.1 \mu$ s and 4 line averages. A total of 1212 successive images were captured with an average mill progression of $5 \mathrm{~nm}$ per image.

The acquired image stacks were loaded into the 3D visualization software "Dragonfly", rendered into 3D models with $5 \mathrm{~nm}$ voxels, and exported into several video files. The video files were loaded into the movie software "Camtasia" and merged into single videos with annotations.

\section{Results}

\subsection{Scanning electron microscopy and electron-microprobe analysis}

The Atlas 5 large-area BSE image mosaic illustrates the textural relationships among pyrobitumen, uraninite, native gold, and other minerals in one representative sample of the Carbon Leader Reef (Fig. 2a, full dataset: http://www.petapixelproject.com/mosaics/Witwatersrand/CL-N6exported-BBV/CL-N6-overview/index.html). Uraninite is the most abundant mineral in the hydrocarbon seams. It occurs within the pyrobitumen matrix (Fig. $2 b, c)$ and varies appreciably in grainsize. In massive, partly filamentous pyrobitumen seams, uraninite grains vary between 5 and 30 $\mu \mathrm{m}$ in diameter and in nodular seams from 15 to $50 \mu \mathrm{m}$ in diameter. In both types of pyrobitumen, the uraninite grains vary in shape from irregular to subangular. Most grains have a delicate internal structure with a "cauliflower-like" appearance (Fig. 3a, b; SFig. 1a, b, c).

Native gold partly coats the pyrobitumen nodules, and also occurs as larger aggregates together with other minerals in the interstices between pyrobitumen nodules (Fig. 2b, c; Fig. 3c). Highresolution SEM images and EPMA-based element-distribution maps show that some native gold occurs at the margins of uraninite grains, and fills irregularly shaped pores within the grains ranging between 0.1 to $1 \mu \mathrm{m}$ in diameter (Fig. 3a, b, f, g, h). Significantly, many of the native gold grains in the interstices are porous (Fig 3c, d).

The uraninite grains commonly have domains of higher lead concentration, which are interpreted to have resulted from the production of radiogenic lead from the decay of uranium. 
Elsewhere they have domains of lower $\mathrm{U}$ concentration that correspond to an increased porosity (Fig. 3f, g, i, j; SFig. 2c, e, f).

On the basis of the information obtained from the Atlas 5 large-area SEM imaging mosaics and EMPA-based element distribution maps, three sites were selected for the preparation of FIB specimens for subsequent high-resolution transmission electron microscopy (HRTEM) investigation (Fig. 2c). Two of the FIB sections were located across uraninite grains (FIB 1 and FIB 2); the remaining FIB section extended from a uraninite grain into the pyrobitumen (FIB 3) (Fig. 2c).

\subsection{Transmission-electron microscopy}

Low-resolution bright-field images and HAADF image mosaics of the FIB foils extracted from the uraninite reveal a delicate, porous, and mineralogically complex internal structure (Fig. 4a, b; SFig. 3). Bright-field and HAADF images of the FIB foils indicate areas in which the uraninite appears to be thicker or thinner; thick regions, i.e., materials which contain an enrichment of heavy atoms, or crystalline materials, appear darker in bright-field TEM images, whereas thin regions or pores appear brighter (SFig. 3a). In HAADF images, thick regions and materials that contain atoms with high atomic numbers appear brighter, whereas pore spaces or thin regions are darker (Figs. 4a, b, 6a, b: black arrows). High-resolution bright-field and HAADF TEM images show that the uraninite grains are complexly-shaped aggregates that are composed of 5 to $7 \mathrm{~nm}$ diameter uraninite nanocrystals; the latter were identified by several sets of lattice planes, e.g., $\{011\},\{111\}$ (Fig. 5a, b; SFig. 3b, c, d). Highangle annular dark-field images of areas of lesser thickness indicate the presence of interconnected areas of small white dots interpreted to represent large masses of uraninite nanocrystals (Fig. 6a, d: black arrows). As the uraninite grains are composed entirely of nanocrystals, we refer to them hereafter as uraninite aggregates.

Many of the pores in the uraninite aggregates are filled with pyrobitumen (Figs. 4a, 6c, d). Highresolution HAADF images of this pyrobitumen reveal the presence of bright spots and bands (Fig. $6 \mathrm{~d}$ : white arrows). High-resolution bright-field TEM images show that these spots and bands are composed of uraninite nanocrystals, which were identified by their $\{011\}$ lattice planes (Fig. 6 e, f)

As noted earlier, the uraninite aggregates also contain pores that are filled with native gold (Figs. 4a, b, 6a, b, c; SFig. 3a, b, c). The TEM images reveal that native gold sited within uraninite aggregates, in turn, contains numerous spherical to ellipsoidal pores (Figs. 6a, b, c, 7a, b, c, d). In HAADF images, these pores have bright rims (Fig. 7a). High-resolution bright-field TEM images of these bright rims reveal the presence of pyrobitumen films with uraninite nanocrystals covering the inner walls of the pores in the gold (Fig. $7 \mathrm{~b}, \mathrm{~d}, \mathrm{e}$ ). In contrast to the uraninite, which is entirely composed of nanocrystals, native gold inclusions appear to be larger crystals of varying sizes based on the continuous nature of their lattice fringes (Fig. 7d, f). The presence of pyrobitumen and uraninite in the rims of the gold pores was confirmed by EELS line-scan analyses, which indicate increased counts for $\mathrm{C}, \mathrm{U}$ and $\mathrm{O}$ (Fig. 8a, b, c). In addition, EDS spot analyses provided the elemental composition of the 
pyrobitumen films in the inner pore wall (Fig. 8d), the gold grain (Fig. 8e) and the surrounding uraninite aggregate (Fig. 8f). In the EELS and EDS analyses (Fig. 8c, d, e, f), the increased count rates of $\mathrm{U}$ and $\mathrm{O}$ correspond to uraninite, $\mathrm{Au}$ to native gold, and $\mathrm{C}$ to pyrobitumen.

As noted earlier, the uraninite aggregates commonly have domains of elevated $\mathrm{Pb}$ concentration (Fig. 3i; SFig. 2e). Detailed examination of the uraninite aggregates by TEM reveals that many of the pores contain galena (Fig. 9a, b, c; SFigs. 4a, 5f, g), an interpretation, which is supported by SEM element-distribution maps (Fig. 9e, f, g; SFig. 5b, c). The galena is commonly surrounded by and appears to have been replaced by another phase, which in HAADF images has a uniform grey color (Fig. 9b, SFig. 5f, g). The SEM element-distribution maps and TEM-EDS point analyses clearly show that this phase differs in composition from galena by containing $\mathrm{O}$ and lower proportions of $\mathrm{Pb}$ and $\mathrm{S}$ (Fig. 9e, f, g, h, SFig. 4b). On the basis of these analyses, the phase is inferred to be a lead sulfate mineral. Because of the similar X-ray energies of $\mathrm{Pb}-\mathrm{Ma}$ and $\mathrm{S}-\mathrm{Ka}$ in the EDS spectrum, it is possible, however, that the $\mathrm{Pb}$ peak masked that of $\mathrm{S}$, and that the phase does not contain S, i.e., that it is a lead oxide. Lattice-fringe images and electron-diffraction patterns were therefore obtained for this phase and compared to $d$ values of possible lead oxide phases (e.g., litharge, plattnerite, massicot, minium, and scrutinyite) and lead sulfate phases (e.g., anglesite and lanarkite). The $d$ values, and angles between the lattice planes did not match to any of the lead oxide phases, but they did match those of the lead sulfate mineral, lanarkite (Fig. 9d, SFig. 4c) (Sahl, 1970). Not unexpectedly, as noted above, the lanarkite replaced the galena (Fig. 9a, b, e, f, g, h; SFig. 5f, g). Lanarkite also occurs as an alteration rim on uraninite aggregates (SFig. 6a, b).

In HAADF images, the boundary between the uraninite aggregates and the pyrobitumen is characterized by a thin white film, which follows the shape of the uraninite aggregates (Fig. 4a, b, SFig. 7a). Elemental line-scan analysis and bright-field images reveal that this zone is composed of uraninite nanocrystals (SFig. 7b, c, d, e). The concentration of uraninite nanocrystals decreases abruptly beyond this zone into the pyrobitumen, and the density of nanocrystals increases towards the aggregates (SFig. $7 \mathrm{c}, \mathrm{d})$.

Phyllosilicates occur within some of the larger pores in uraninite and in fractures (SFig. 3). Point analyses indicate that $\mathrm{Al}, \mathrm{Si}$, and $\mathrm{O}$ as the main constituents; the $\mathrm{Al}$ peak is approximately half the height of the Si peak (SFig. 4d). This composition and the failure to detect appropriate interlayer cations in the EDS point analyses (e.g., $\mathrm{K}, \mathrm{Na}, \mathrm{Mg}$ ) suggest that the phyllosilicate phase is probably pyrophyllite.

\subsection{D focused-ion beam (FIB-SEM) nanotomography}

The 3D focused-ion beam nanotomography was conducted to visualize (i) the delicate internal structure of the uraninite-nanocrystal aggregates, (ii) the volume and distribution of the enclosed gold grains and (iii) the shape and distribution of uraninite- and pyrobitumen-filled pore holes in the gold grains. The still image (Fig. 10) and the related video (Video 1) of the nanotomography reveal that the 
uraninite aggregate hosts a significant volume of gold in its micro-pores and fractures, which are distributed through the entire aggregate. All the gold grains, in turn, have a large volume of spherical to ellipsoidal pores (described in detail in the preceding section), strengthening the case of abundant pyrobitumen and uraninite nanocrystal inclusions in the gold.

\section{Discussion}

\subsection{The nature of the uraninite in pyrobitumen}

Most studies on the uraninite grains in the Witwatersrand consider it to be a detrital mineral derived from a granitiod source-rock (Depiné et al., 2013; England et al., 2001; Frimmel et al., 2005). This is certainly true for the larger, compact uraninite crystals with abraded and rounded grain boundaries that occur in many reefs. A recent study by Fuchs et al. (2015), however, provided evidence for the in situ growth of single 5-7 nm sized nanocrystals of uraninite, and the accumulation of the latter as small uraninite-nanocrystal aggregates $(\sim 200 \mathrm{~nm}-1.5 \mu \mathrm{m}$ diameter $)$ in the visibly mineral-free pyrobitumen of the Carbon Leader Reef. Our current study demonstrated that at least some of the uraninite "grains" in the Witwatersrand Supergroup and all of the uraninite investigated in the Carbon Leader Reef is not of detrital origin. According to Fuchs et al. (2015), liquid hydrocarbons (oils) dissolved pre-exiting detrital uraninite and Ti-bearing minerals while migrating though the Witwatersrand basin, transported uranium, titanium and lead either as dissolved species or as nanoparticles, and released them in the Carbon Leader Reef as nanocrystals during the conversion of liquid oil to pyrobitumen. This interpretation, as noted earlier, is supported by the ubiquitous and homogeneous distribution of uranium and related trace elements in the hydrocarbons (Fuchs et al., 2016).

The results of the current study build on the study of Fuchs et al. (2015) by expanding the examination of uraninite in the Carbon Leader Reef to grains between 5 and $50 \mu \mathrm{m}$ in diameter. These grains are considerably different from the massive, compact and rounded uraninite grains that are observed elsewhere in the Witwatersrand Supergroup, and are commonly interpreted to be of detrital origin (e.g., Depiné et al., 2013; England et al., 2001). Uraninite grains observed in our samples of the Carbon Leader Reef are confined to pyrobitumen seams, and are subangular and porous, with a delicate "cauliflower-like" internal structure. High-resolution TEM images show that the uraninite grains in the Carbon Leader Reef consist entirely of nanocrystalline masses of uniform size, and are thus aggregates rather than single crystals. This, and the occurrence of discrete uraninite nanocrystals in the pyrobitumen, confirm the conclusion of Fuchs et al. (2015) that the source of uraninite in the Carbon Leader Reef lies within the pyrobitumen. They showed, moreover, that the larger grains were the product of aggregation through crystal-by-crystal alignment (oriented attachment), and that this very likely occurred during the conversion of liquid hydrocarbons to pyrobitumen. We propose, 
therefore, that hydrocarbon liquids dissolved detrital uraninite, en route to the Carbon-Leader Reef and perhaps within it. In the Carbon Leader Reef, uranium precipitated initially as individual nanocrystals and later as aggregates, owing probably to flocculation induced by interaction of the hydrocarbon liquid with hydrothermal fluid. During flocculation, continuous alignment of uraninite nanocrystal layers around smaller aggregates led to the growth of large uraninite grains reaching up to $50 \mu \mathrm{m}$ in diameter and to the development of the cauliflower-like and porous character of the grains.

\subsection{The hydrothermal mineralization of gold in uraninite}

Observations of native gold lining uraninite aggregates and filling pores within them provide evidence that deposition of native gold postdated the growth of the uraninite aggregates. Moreover, they strongly suggest a genetic relationship between the uraninite and the native gold. There is general agreement that hydrothermal fluids mobilized gold within the Witwatersand basin (Frimmel, 1997; Frimmel et al., 2005; Kirk et al., 2002; Minter et al., 1993; Pretorius, 1991), and according to some, the gold is entirely hydrothermal in origin (Barnicoat et al., 1997; Law and Phillips, 2005; Phillips and Law, 1994; Phillips et al., 1997; Phillips and Myers, 1989; Phillips and Powell, 2011). From studies of fluid inclusions in quartz, these fluids are interpreted to have been moderately saline, of intermediate $\mathrm{pH}$, slightly reducing, and to have reached maximum temperatures of $300^{\circ}$ to $350^{\circ} \mathrm{C}$ (Drennan et al., 1999). However, although some authors have attributed the association of the native gold with pyrobitumen to reduction of $\mathrm{Au}^{+}$species (e.g., $\mathrm{Au}(\mathrm{HS})^{\circ}$ ) to $\mathrm{Au}^{\circ}$ by the organic matter (Drennan et al., 1999; Fuchs et al., 2016; Heinrich, 2015; Phillips and Powell, 2011; Robb and Meyer, 1995), the relationships involving native gold, uraninite and pyrobitumen have not been considered in detail.

The textural association of hydrothermal minerals with hydrocarbons in the Carbon Leader Reef (e.g., Fig. 2b, c - filamentous gold deposited around pyrobitumen nodules; SFigs. 3a, 4f phyllosilicates in larger pores, microfractures in pyrobitumen) shows that hydrothermal liquids infiltrated the Carbon Leader when liquid hydrocarbons were present in the reefs, thereby permitting interaction between the two liquids. Indeed, the presence of pyrobitumen in spherical to slightly ellipsoidal pores in native gold inclusions in uraninite aggregates (Fig. 7a, b, c and d) shows that droplets of oil (liquid hydrocarbons) developed in the hydrothermal fluid and that these were trapped by the growing crystals of native gold. The observation that these pores are now only partly filled (pyrobitumen coats the walls of the pores) reflects the shrinkage of the liquid because of loss of volatiles and the conversion of the liquid to pyrobitumen (e.g., Tissot and Welte, 1984).

We propose that interaction of immiscible auriferous hydrothermal liquid with uraniferous hydrocarbon liquid in the Carbon Leader Reef led to the formation of micro-emulsions of oil and water, i.e., microdroplets of oil in water and vice versa (Lagaly et al., 1997). We further propose that precipitation of native gold was triggered by the formation of the oil-in-water emulsion. Under the conditions of hydrothermal gold transport (intermediate $\mathrm{pH}$ of 4 to 5 , slightly reducing $\mathrm{fO}_{2}$ and $\mathrm{T}<$ 
$350^{\circ} \mathrm{C}$ ), the gold would have been highly soluble as bisulfide complexes $\left(\mathrm{Au}(\mathrm{HS})^{\circ}\right.$ ) (Williams-Jones et al., 2009; Williams-Jones and Migdisov, 2014). However, where the hydrothermal fluid came in contact with the hydrocarbon liquid, it would have become strongly reduced and precipitated native gold around the micro-droplets of oil owing to the reactions:

$$
\begin{gathered}
\mathrm{C}+\mathrm{O}_{2}=\mathrm{CO}_{2} \\
\mathrm{Au}(\mathrm{HS})^{\circ}+0.5 \mathrm{H}_{2} \mathrm{O}=\mathrm{Gold}+0.25 \mathrm{O}_{2}+\mathrm{H}_{2} \mathrm{~S}
\end{gathered}
$$

Where the micro-emulsion of oil in water infiltrated aggregates of uraninite nanocrystals, the sizes of the native gold crystals were determined by the sizes of the pores within the uraninite grains and ranged between 0.1 and $1 \mu \mathrm{m}$. The relatively low viscosity of the two fluids and the fact that crystal growth is favored energetically over crystal nucleation ensured that each pore in a uraninite aggregate was filled by gold crystals of variable grain size, as documented in high-resolution TEM images. The pores in these gold crystals preserve the record of the droplets of the former micro-emulsions. Significantly, as noted earlier, the pyrobitumen seams lining the inner walls of the pores contain single $5-7 \mathrm{~nm}$ long nanocrystals of uraninite similar to the uraninite nanocrystals that formed the large uraninite aggregates (discussed in section 6.1) and indistinguishable from the single nanocrystals observed in the pyrobitumen seams and nodules (reported by Fuchs et al., 2015). Nonetheless, the presence of in situ-grown uraninite nanocrystals in pyrobitumen within the pores in native gold provides compelling evidence that uranium was transported by hydrocarbon liquids and crystallized largely by the interaction of these liquids with auriferous hydrothermal fluids.

\subsection{The formation of galena and lanarkite}

In addition to native gold, galena also fills pores and micro-fractures in the uraninite aggregates. This suggests that the hydrothermal fluids that deposited the gold in these pores were responsible for the formation of galena. The lead required for the formation of galena was most likely contributed by the same hydrocarbon fluid that transported uranium. A plausible source for the lead therefore is the detrital uraninite occurring elsewhere in the Witwatersrand Basin, which we propose was the source of the uranium. This interpretation is supported by the observation that most of the lead in the galena is radiogenic (Fuchs et al., 2016). As authigenic pyrite resulting from sulfidation of Fe-oxide and $\mathrm{Fe}$ silicate minerals by hydrothermal fluids is widely observed in the Witwatersrand reefs (Hofmann et al., 2009), it is reasonable to conclude that the hydrothermal fluids interacting with the hydrocarbon liquids had relatively high sulfur activity, thereby facilitating the formation of galena. The sulfurbearing aqueous fluids, however, did not permeate entire uraninite aggregates, but moved along selected networks of pores and fractures, in which galena precipitated (Fig. 3i, j, SFig. 2e, f; SFig. 5a, b, $c, f, g)$.

Lanarkite, a lead sulfate mineral with the chemical formula $\mathrm{Pb}_{2}\left(\mathrm{SO}_{4}\right) \mathrm{O}$, which has not been reported previously in rocks of the Witwatersrand Supergroup, was observed at the interfaces between galena and uraninite. It is a very rare mineral that only has been observed previously with anglesite as 
an oxidation product of galena (Abdul-Samad, 1982; Sahl, 1970), and was therefore not expected in the very reducing environment of the Carbon Leader Reef. A possible explanation for its occurrence at the interface between galena and uraninite is the development of a zone of local oxidation of the uraninite by the hydrothermal fluid according to a reaction of the type:

$$
\mathrm{U}_{3} \mathrm{O}_{8}+6 \mathrm{H}_{2} \mathrm{O} \rightarrow 3 \mathrm{U}(\mathrm{OH})_{4}+\mathrm{O}_{2} .
$$

Alternatively, the oxygen could have been produced by radiation of the pore solution due to the decay of uranium (Janeczek and Ewing, 1992). The alpha radiation of pore water at the uraninite - galena interface could have caused the dissociation of the water molecules into hydrogen and hydroxyl radicals as well as other oxygen-bearing aqueous species, which may have sufficiently increased oxygen fugacity to permit the production of lanarkite at the expense of galena.

\subsection{A mineralization model for formation of uraninite, gold and associated minerals}

Based on the results of this study, we propose the following unifying mineralization model for the formation of the uraninite and enclosed gold in the Carbon Leader Reef. This model involves oil-inwater micro-emulsions and is illustrated in the simplified sketch in Figure 11. According to this model, liquid hydrocarbons were produced from the carbonaceous shale units within the West and Central Rand Groups of the Witwatersrand Supergroup, migrated upward and were eventually introduced into the Carbon Leader Reef. As first proposed by Fuchs et al. (2015), these oils dissolved detrital uraninite residing in coarse-grained clastic rocks en route to or within other portions of the Carbon Leader Reef.

When the liquid hydrocarbons entered the sedimentary rocks of the Carbon Leader Reef, the fluid pressure caused vertical extension (Fig. 11a), resulting in bedding-parallel hydrocarbon veins and seams. The absence of clearly detrital minerals within the pyrobitumen (Fig. 2a, b, c) indicates that the expansion dislocated detrital components by forming layers of pure hydrocarbons that are bound by detrital minerals (Fig. 11a). Thermal alteration due to the progressive increase in temperature in the Carbon Leader sediments that accompanied their burial led to the conversion of the hydrocarbon liquids to the pyrobitumen residue and the precipitation of uraninite nanocrystals. Interaction of the hydrocarbon liquid with a much hotter hydrothermal fluid at this time also likely induced flocculation of the uraninite nanoparticles to form porous aggregates up to $50 \mu \mathrm{m}$ in diameter (Fig. 11b).

Hydrothermal (aqueous) fluids (re)mobilized gold and other metals (such as Ag and Te, see Fuchs et al. (2016)) and transported them into the Carbon Leader Reef. When the auriferous hydrothermal fluids invaded the sediments of the Carbon Leader Reefs and interacted with the hydrocarbon liquids, they also entered into the oil-filled pores and microfractures of the uraninite aggregates. There they interacted with the hydrocarbon liquid by forming an oil-in-water emulsion with water as the outer, coherent phase and oil droplets as the inner, dispersed phase (Fig. 11c). Oil droplets coalesced (probably due to growth by Ostwald ripening), increased in size and formed seams of larger nodules as shown in Figure 2a, b. 
In the newly formed emulsion, native gold was precipitated from the hydrothermal solution because of the sharp reduction in the oxygen fugacity of the latter that accompanied its interaction with the hydrocarbon liquid. Native gold precipitated on the surfaces of the nodules and smaller oil droplets within the pores of the uraninite (Fig. 11c, d). Oil droplets were entrapped within the gold crystals by the rapid crystallization of gold within the uraninite pores (Fig. 11e). The temperature increase in the Carbon Leader Reef due to burial and the presence of hot hydrothermal fluids caused the thermal alteration and conversion of the oil inclusions into a pyrobitumen residue (Fig. 11f). This process was accompanied by the volumetric shrinkage ("coking") of the hydrocarbon liquid into a pyrobitumen mesophase and the production of volatiles (e.g., methane) that left the system. Owing to the destruction of organo-metallic ligands, single nanocrystals of uraninite crystallized from the hydrocarbons isolated within the pores of the gold grains (Fig. 11g).

The formation of galena in the pores of the uraninite aggregates was facilitated by a supply of $\mathrm{Pb}$ from the hydrocarbon liquid, and sulfur from the hydrothermal fluid. Lanarkite, a very rare lead sulfate, formed at the interface between galena and uraninite, probably because of the creation of a micro-environment of elevated oxygen fugacity through radiolysis of the hydrothermal fluid or production of oxygen during reaction of the uraninite with this fluid (Fig. 11h).

\subsection{Implications for existing genetic models for the Witwatersrand deposits}

Previous authors including two recent ones, i.e., Depiné et al. (2013) and Frimmel et al. (2013), have interpreted the uraninite in the Witwatersrand Supergroup to be of detrital origin. This includes uraninite that carries gold, a feature of the uraninite that is interpreted to be either pre-depositional and source-specific or a post-depositional phenomenon involving infiltration of gold-bearing fluids into pores created by metamictization of the uraninite grains. The results of this study show, however, that a significant proportion of the uraninite, namely all of the investigated uraninite in the Carbon Leader Reef is not detrital (this includes auriferous and non-auriferous varieties), and instead grew in situ from a hydrocarbon liquid. This does not preclude the former or present existence of detrital uraninite in the Carbon Leader Reef because, as proposed earlier, detrital uraninite is the most likely source of the uranium that formed the uraninite aggregates now present in the carbons seams of the investigated portion of the reef. The hypothesis that the uraninite aggregates in the investigated samples are the product of metamictization of pre-existing (detrital) uraninite is easily rejected, however: 1) on the grounds that the uraninite grains are composed of uraninite nanocrystals (this study); 2) because uraninite is resistant to $\alpha$-decay damage due to a high rate of self-annealing that prevents metamictization (e.g., Hazen et al., 2009; Janeczek and Ewing, 1991); and 3) because the uraninite grains lack morphological features that are diagnostic of metamictization (e.g., amorphous structures).

In this study, we have provided direct evidence that the gold in the Carbon Leader Reef was transported as a dissolved phase in a hydrothermal fluid and was deposited on oil droplets by the 
reduction of the hydrothermal fluid by the hydrocarbon phase. Given the high potential of hydrothermal (aqueous) solutions to transport gold over appreciable distances and the capability of hydrocarbons to concentrate gold efficiently, both the hydrothermal model (long-range transport of gold from outside the basin) and the modified paleoplacer model (short-range transport mainly internal to the reef) are plausible. However, the recently proposed models involving precipitation of the gold on microbial mats (Frimmel and Hennigh, 2015; Heinrich, 2015) are not supported by the results of this study.

\section{Conclusions}

In this paper, we have shown that water-oil micro-emulsions were responsible for the concentration of uranium and gold in the Carbon Leader Reef. Hydrocarbon liquids released from carbonaceous shales deeper in the Witwatersrand Basin dissolved detrital uraninite and migrated upwards into the Carbon Leader Reef, where they precipitated uraninite nanocrystals. Interaction of uranium-bearing liquid hydrocarbons and gold-bearing hydrothermal fluids led to the formation of water-oil and oil-water micro-emulsions, the in situ growth (flocculation) of large aggregates of uraninite nanocrystals (up to $50 \mu \mathrm{m}$ in diameter), precipitation of native gold in pores within this uraninite, and the formation of individual uraninite nanocrystals in fossil oil droplets (pyrobitumen) in the native gold. The aqueous gold species were reduced from the +1 to the 0 state by the dispersant oil phase, initiating gold precipitation on the oil droplets. The rapid release and growth of gold crystals entrapped masses of oil inclusions that were later converted into pyrobitumen. Single nanocrystals of uraninite were released from the oil during this process and concentrated within the pyrobitumen residue in pores in the gold. Galena was also precipitated in the pores of the uraninite, possibly owing to the transport of $\mathrm{Pb}$ by the hydrocarbon liquid and its interaction with $\mathrm{H}_{2} \mathrm{~S}$-rich hydrothermal fluids. Development of local oxidizing zones at galena-uraninite interfaces, either because of the radioactive decomposition of the hydrothermal fluid (the water) or reaction of the latter with uraninite, led to the formation of lanarkite. Although our observations are limited to uraninite in the Carbon Leader Reef and their gold inclusions, the process of gold and uranium concentration through the interaction of hydrocarbon and hydrothermal fluids may also apply to other ore horizons of the Witwatersrand Supergroup (Vaal Reef, B-Reef, Denney's Reefs, etc.), that are rich in organic matter.

\section{Acknowledgements}

We thank AngloGold Ashanti and Thomas Oberthür of the BGR who provided additional samples for the study. Richard Wirth and Anja Schreiber of the GFZ Potsdam are thanked for the preparation of the FIB sections. Robert Martin is thanked for the critical discussions and editorial advices, which 
helped us to improve this manuscript. Financial support for the research was provided by a NSERC Discovery grant to AEW-J.

\section{References}

Abdul-Samad, F.A., 1982. Chemistry of formation of lanarkite, Pb2OSO4. Mineral. Mag. 46, 499. AngloGoldAshanti, 2014. Mineral resource and ore reserve report 2014. AngloGold Ashanti, New Town, South Africa, p. 196.

Armstrong, R.A., Compston, W., Retief, E.A., Williams, I.S., Welke, H.J., 1991. Zircon ion microprobe studies bearing on the age and evolution of the Witwatersrand triad. Precambrian Res. 53, 243-266.

Barnicoat, A.C., Henderson, I.H.C., Knipe, R.J., Yardley, B.W.D., Napier, R.W., Fox, N.P.C., Kenyon, A.K., Muntingh, D.J., Strydom, D., Winkler, K.S., Lawrence, S.R., Cornford, C., 1997. Hydrothermal gold mineralization in the Witwatersrand basin. Nature 386, 820-824.

Coward, M.P., Spencer, R.M., Spencer, C.E., 1995. Development of the Witwatersrand Basin, South Africa. Geol. Soc. London Spec. Publ. 95, 243-269.

Depiné, M., Frimmel, H.E., Emsbo, P., Koenig, A.E., Kern, M., 2013. Trace element distribution in uraninite from Mesoarchaean Witwatersrand conglomerates (South Africa) supports placer model and magmatogenic source. Mineral. Deposita 48, 423-435.

Drennan, G.R., Boiron, M.C., Cathelineau, M., Robb, L.J., 1999. Characteristics of postdepositional fluids in the Witwatersrand Basin. Miner. Petrol. 66, 83-109.

Drennan, G.R., Robb, L.J., 2006. The nature of hydrocarbons and related fluids in the Witwatersrand Basin, South Africa: Their role in metal redistribution. Geol. Soc. Am. S. 405, 353-385.

Dutkiewicz, A., Rasmussen, B., Buick, R., 1998. Oil preserved in fluid inclusions in Archaean sandstones. Nature 395, 885-888.

England, G.L., Rasmussen, B., Krapež, B., Groves, D.I., 2001. The origin of uraninite, bitumen nodules, and carbon seams in Witwatersrand gold-uranium-pyrite ore deposits, based on a PermoTriassic analogue. Econ. Geol. 96, 1907-1920.

England, G.L., Rasmussen, B., Krapež, B., Groves, D.I., 2002. Archaean oil migration in the Witwatersrand Basin of South Africa. J. Geol. Soc. London 159, 189-201.

Frimmel, H., Hennigh, Q., 2015. First whiffs of atmospheric oxygen triggered onset of crustal gold cycle. Mineral. Deposita 50, 5-23.

Frimmel, H.E., 1997. Detrital origin of hydrothermal Witwatersrand gold - a review. Terra Nova 9, 192-197.

Frimmel, H.E., Depiné, M., Emsbo, P., Koenig, A.E., Kern, M., 2013. Reply to comments by T. Oberthür on "Trace element distribution in uraninite from Mesoarchaean Witwatersrand 
conglomerates (South Africa) supports placer model and magmatogenic source". Mineral. Deposita 48, 1051-1053.

Frimmel, H.E., Groves, D.I., Kirk, J., Ruiz, J., Chezley, J., Minter, W.E.L., 2005. The formation and preservation of the Witwatersrand Goldfields, the world's largest gold province, in: Hedenquist, J.W., Thompson, J.F.H., Goldfarb, R.J., Richards, J.P. (Eds.), One Hundreth Anniversary Volume. Society of Economic Geologists, Inc., Littleton, Colerado, pp. 769-797.

Fuchs, S., Przybylowicz, W.J., Williams-Jones, A.E., 2014. Elemental imaging of organic matter and associated metals in ore deposits using micro-PIXE and micro-EBS. Nucl. Instrum. Meth. B. 318, Part A, 157-162.

Fuchs, S., Schumann, D., Williams-Jones, A.E., Vali, H., 2015. The growth and concentration of uranium and titanium minerals in hydrocarbons of the Carbon Leader Reef, Witwatersrand Supergroup, South Africa. Chem. Geol. 393-394, 55-66.

Fuchs, S., Williams-Jones, A.E., Jackson, S.E., Przyblowicz, W., 2016. Metal distribution in pyrobitumen of the Carbon Leader Reef, Witwatersrand Supergroup, South Africa: Evidence for liquid hydrocarbon ore fluids. Chem. Geol. 426, 45-59.

Gray, G.J., Lawrence, S.R., Kenyon, K., Cornford, C., 1998. Nature and origin of "carbon" in the Archean Witwatersrand Basin, South Africa. J. Geol. Soc. London 155, 39-59.

Grové, D., Harris, C., 2010. O- and H-isotope study of the Carbon Leader Reef at the Tau Tona and Savuka mines (Western Deep Levels), South Africa: Implications for the origin and evolution of Witwatersrand basin fluids. S. Afr. J. Geol. 113, 75-88.

Hallbauer, D.K., 1975. Plant origin of the Witwatersrand carbon. Miner. Sci. Eng. 7, 111-131.

Hallbauer, D.K., 1986. The mineralogy and geochemistry of Witwatersrand pyrite, gold, uranium and carbonaceous matter, in: Anhauesser, C.R., Maske, C.R. (Eds.), Mineral Deposits of Southern Africa. Geological Society of South Africa, Johannesburg, pp. 731-751.

Hallbauer, D.K., van Warmelo, K.T., 1974. Fossilized plants in thucholite from Precambrian rocks of the Witwatersrand, South Africa. Precambrian Res. 1, 199-212.

Hazen, R.M., Ewing, R.C., Sverjensky, D.A., 2009. Evolution of uranium and thorium minerals. Am. Mineral. 94, 1293-1311.

Heinrich, C.A., 2015. Witwatersrand gold deposits formed by volcanic rain, anoxic rivers and Archaean life. Nat. Geosci. 8, 206-209.

Hofmann, A., Bekker, A., Rouxel, O., Rumble, D., Master, S., 2009. Multiple sulphur and iron isotope composition of detrital pyrite in Archaean sedimentary rocks: A new tool for provenance analysis. Earth Planet. Sci. Lett. 286, 436-445.

Janeczek, J., Ewing, R.C., 1991. X-ray powder diffraction study of annealed uraninite. J. Nucl. Mater. 185, 66-77. 
Janeczek, J., Ewing, R.C., 1992. Dissolution and alteration of uraninite under reducing conditions. J. Nucl. Mater. 190, 157-173.

Kirk, J., Ruiz, J., Chesley, J., Walshe, J., England, G., 2002. A major Archean, gold- and crustforming event in the Kaapvaal craton, South Africa. Science 297, 1856-1858.

Kositcin, N., Krapež, B., 2004. Relationship between detrital zircon age-spectra and the tectonic evolution of the Late Archaean Witwatersrand Basin, South Africa. Precambrian Res. 129, 141-168.

Lagaly, G., Schulz, O., Zimehl, R., 1997. Dispersionen und Emulsionen. Eine Einführung die Kolloidik feinverteilter Stoffe einschließlich der Tonminerale. Steinkopff-Verlag, Darmstadt.

Law, J.D.M., Phillips, G.N., 2005. Hydrothermal replacement model for Witwatersrand gold, in: Hedenquist, J.W., Thompson, J.F.H., Goldfarb, R.J., Richards, J.P. (Eds.), One Hundreth Anniversary Volume. Society of Economic Geologists, Inc., Littleton, Colorado, pp. 799-811.

Minter, W.E.L., Goedhart, M., Knight, J., Frimmel, H.E., 1993. Morphology of Witwatersrand gold grains from the Basal Reef - evidence for their detrital origin. Econ. Geol. Bull. Soc. 88, 237-248.

Mossman, D., Minter, W.E.L., Dutkiewicz, A., Hallbauer, D.K., George, S.C., Hennigh, Q., Reimer, T.O., Horscroft, F.D., 2008. The indigenous origin of Witwatersrand "carbon". Precambrian Res. 164, 173-186.

Nagy, B., 1993. Kerogens and bitumens in Precambrian uraniferous ore deposits: Witwatersrand, South Africa, Elliot Lake, Canada, and the natural fission reactors, Oklo, Gabon, in: Parnell, J., Kucha, H., Landais, P. (Eds.), Bitumens in Ore Deposits. Soc. Geol. Appl. Miner. Deposits, Berlin, pp. 287-333. Phillips, G.N., Law, J.D.M., 1994. Metamorphism of the Witwatersrand gold fields - a review. Ore Geol. Rev. 9, 1-31.

Phillips, G.N., Law, J.D.M., 2000. Witwatersrand gold fields: geology, genesis, and exploration. Rev. Econ. Geol. 13, 439-500.

Phillips, G.N., Law, J.D.M., Stevens, G., 1997. Alteration, heat, and Witwatersrand gold: 111 years after Harrison and Langlaagte. S. Afr. J. Geol. 100, 377-392.

Phillips, G.N., Myers, R.E., 1989. The Witwatersrand gold fields: part II. An origin for Witwatersrand gold during metamorphism and associated alteration, in: Keays, R.R., Ramsay, W.R.H., Groves, D.I. (Eds.), The geology of gold deposits: the perspective in 1988. Society of Economic Geologists, New Haven, pp. 598-608.

Phillips, G.N., Powell, R., 2011. Origin of Witwatersrand gold: a metamorphic devolatilisationhydrothermal replacement model. Trans. Inst. Min. Metall. B. 120, 112-129.

Pretorius, D.A., 1991. The sources of Witwatersrand gold and uranium: A continued difference of opinion, in: Hutchinson, R.W., Grauch, R.I. (Eds.), Historical Perspectives of Genetic Concepts and Case Histories of Famous Discoveries. Economic Geology Monograph 8, New Haven, pp. 1-36.

Robb, L.J., Meyer, F.M., 1991. A contribution to recent debate concerning epigenetic versus syngenetic mineralization processes in the Witwatersrand Basin. Econ. Geol. Bull. Soc. 86, 396-401. 
Robb, L.J., Meyer, F.M., 1995. The Witwatersrand Basin, South Africa: Geological framework and mineralization processes. Ore Geol. Rev. 10, 67-94.

Sahl, K., 1970. Kristallstruktur von Lanarkit, $\mathrm{Pb} 2 \mathrm{O}[\mathrm{SO} 4]$. Z. Kristallogr. 132, 99-117.

Schidlowski, M., 1981. Uraniferous constituents of the Witwatersrand conglomerates: oremicroscopic observations and implications for Witwatersrand metallogeny. U.S. Geol. Surv. Prof. Paper, N1-N29.

Tissot, B.P., Welte, D.H., 1984. Petroleum formation and occurrence, 2 ed. Springer-Verlag, Berlin. Williams-Jones, A.E., Bowell, R.J., Migdisov, A.A., 2009. Gold in solution. Elements 5, 281-287.

Williams-Jones, A.E., Migdisov, A.A., 2014. Experimental constraints on the transport and deposition of metals in ore-forming hydrothermal systems, in: Kelley, K.D., Howard, C.G. (Eds.), Building Exploration Capability for the 21st Century. Society of Economic Geologists, pp. 77-95.

Wirth, R., 2004. Focused Ion Beam (FIB): A novel technology for advanced application of microand nanoanalysis in geosciences and applied mineralogy. Eur. J. Mineral. 16, 863-876.

Wirth, R., 2009. Focused Ion Beam (FIB) combined with SEM and TEM: Advanced analytical tools for studies of chemical composition, microstructure and crystal structure in geomaterials on a nanometre scale. Chem. Geol. 261, 217-229. 


\section{Figures}

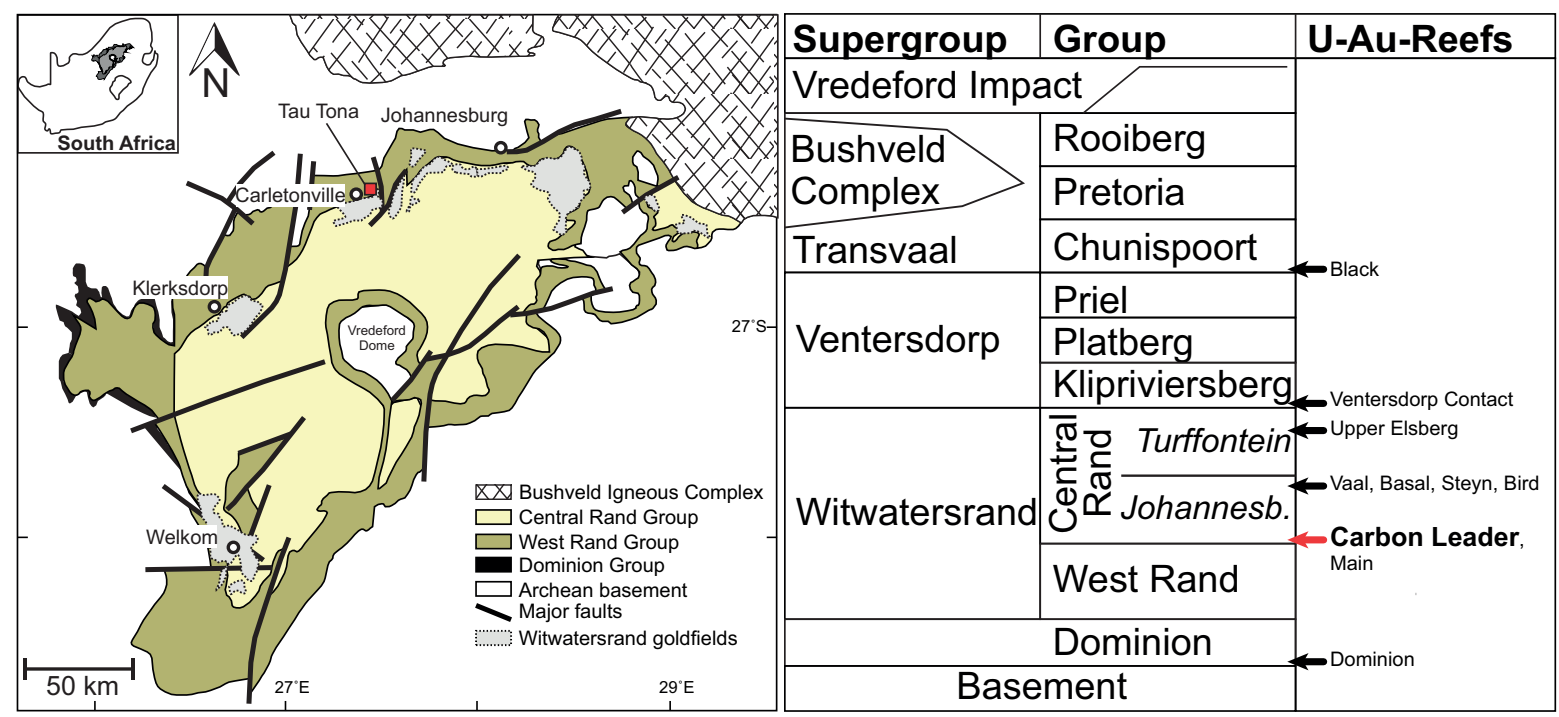

Figure 1 Geological map and stratigraphic column for the Witwatersrand Basin and surrounding areas showing the location of the study site and the stratigraphic positions of the main ore horizons (modified from England et al., 2002; Frimmel et al., 2005). 


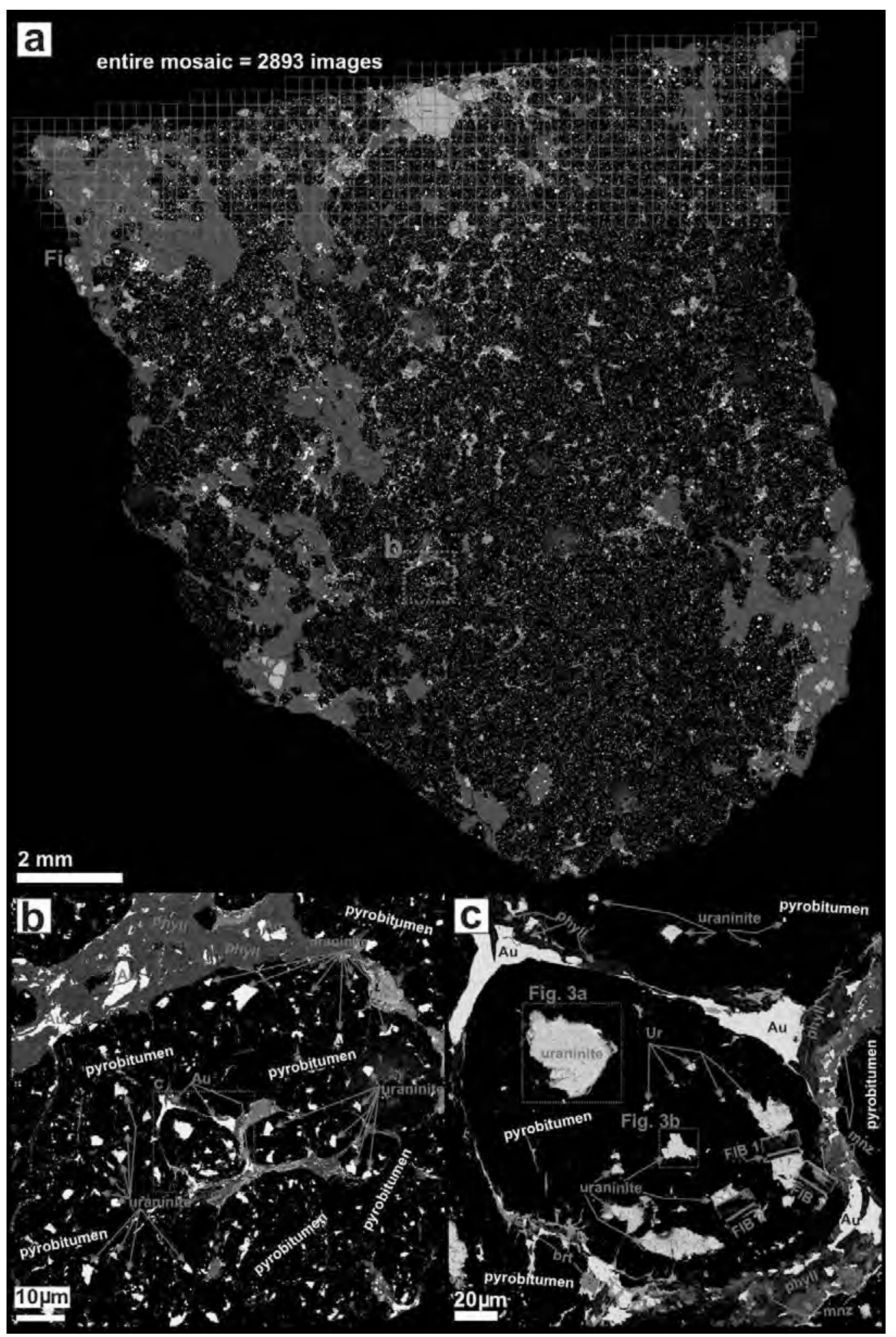

Figure 2 Backscattered electron (BSE) SEM images of a Carbon Leader Reef sample. (a) Atlas 5 large-area SEM image mosaic of the entire sample. (b) Higher-resolution SEM-BSE image mosaic of area "b" in image (a). The image shows pyrobitumen nodules that contain irregularly shaped uraninite grains. (c) Enlargement of a pyrobitumen nodule with irregular uraninite grains. Native gold in contact with the pyrobitumen nodule. The location of FIB foil extraction sites is shown in (c). Abbreviations: Au = gold, brannerite = brt, $\mathrm{mnz}=$ monazite$(\mathrm{Ce})$, phyll $=$ phyllosilicates . 

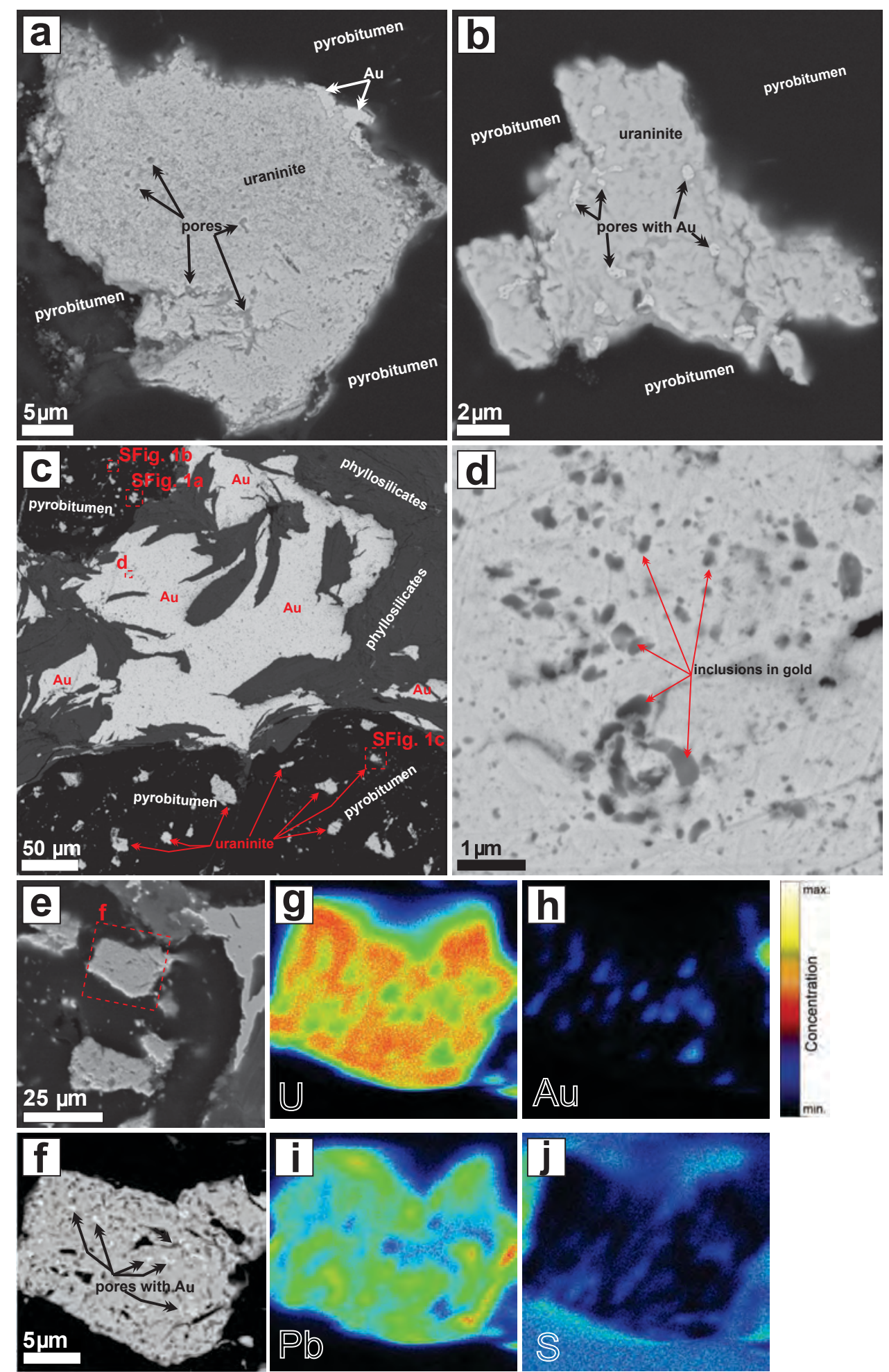

Figure 3 Backscattered electron SEM images and EPMA-based element-distribution maps of uraninite aggregates. (a, b) Uraninite aggregates identified by the red boxes in Fig. 2c. (c) Fibrous grains of native gold and pyrobitumen nodules from the area marked "Fig. 3c" in Figure 2a. (d) Enlargement of area "d" in the gold grain shown in (c). (e) SEM-BSE image of the uraninite grain shown in Figure 2c before FIB specimen 2 was extracted. (f) Enlargement of the uraninite grain in (e). (g, h, i, j) Electron-microprobe-based element-distribution maps of $\mathrm{U}, \mathrm{Au}, \mathrm{Pb}$, and $\mathrm{S}$ of the uraninite aggregate shown in (f). 

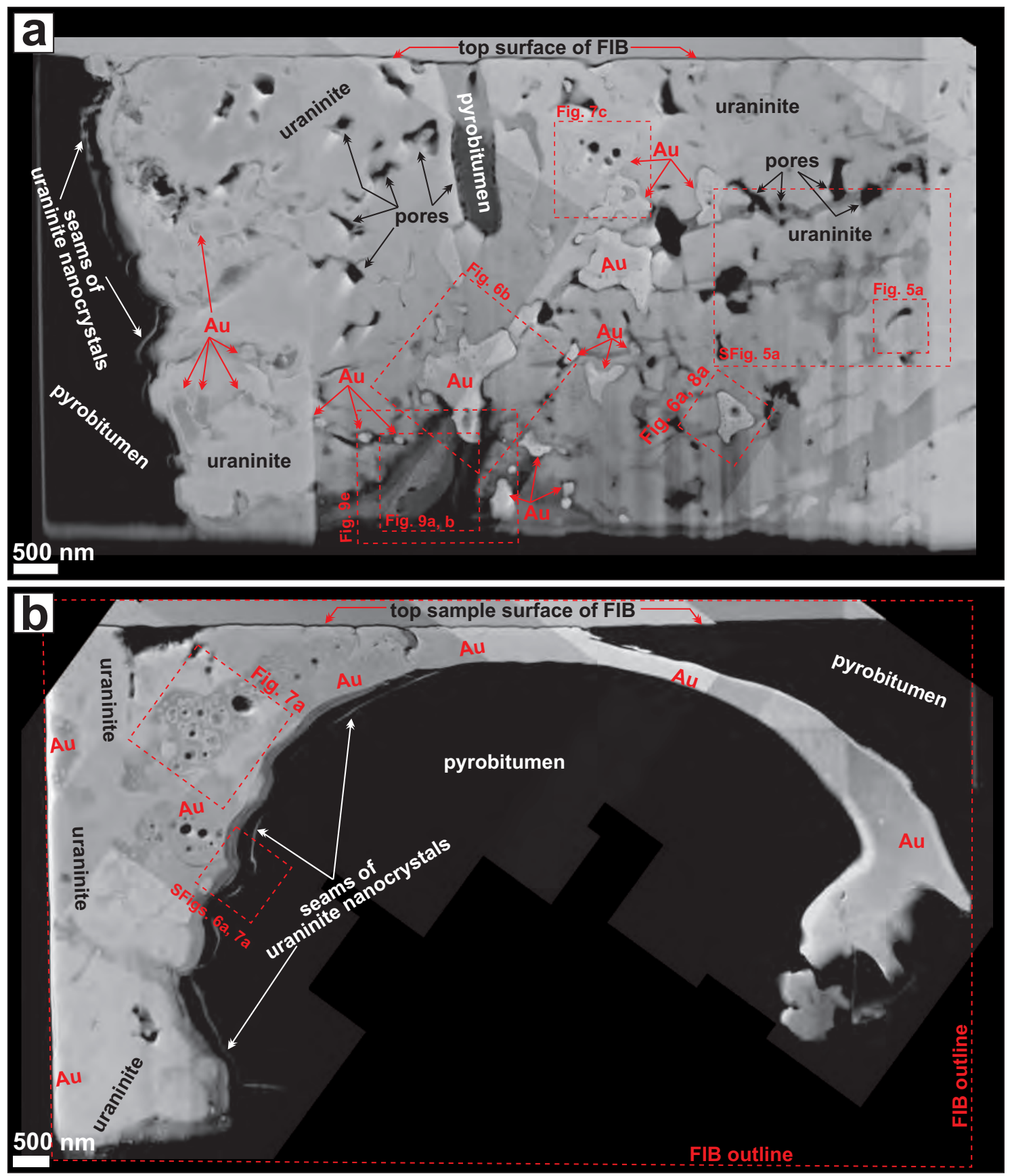

Figure 4 High-angle annular dark-field (HAADF) TEM image mosaics of (a) FIB foil 1 showing native gold and pyrobitumen filling pores and micro-fractures in uraninite aggregates and (b) of FIB foil 3 showing porous native gold inclusions in a uraninite aggregate. 

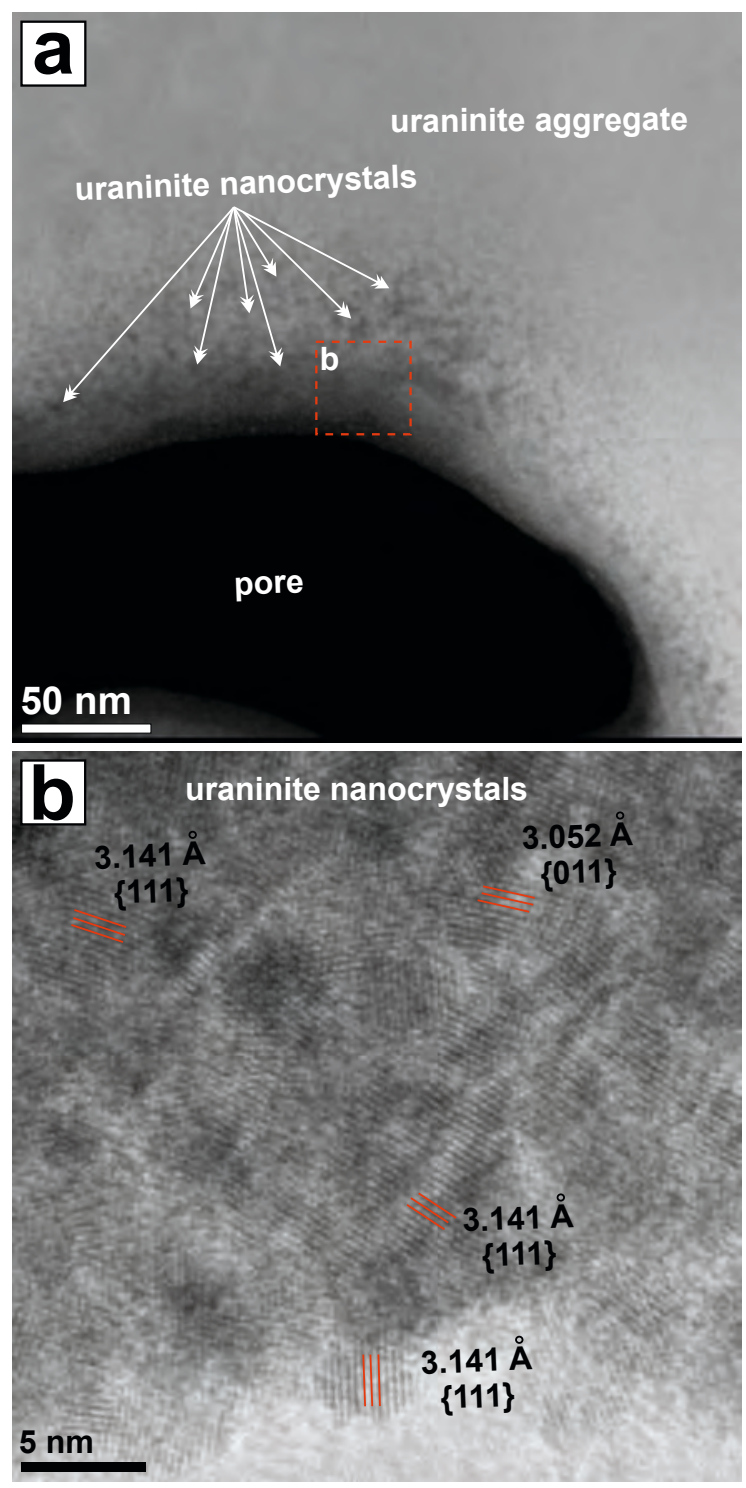

Figure 5 High-angle annular dark-field (HAADF) and bright-field TEM image of a uraninite aggregate. (a) The HAADF image of area "Fig. 5a" marked in Figure 4a shows that the uraninite is an aggregate consisting entirely of nanocrystals. (b) The bright-field TEM image of area "b" marked in (a) displays $3-7 \mathrm{~nm}$ diameter uraninite nanocrystals that are identified by their $\{011\}$ and $\{111\}$ families of lattice planes. 


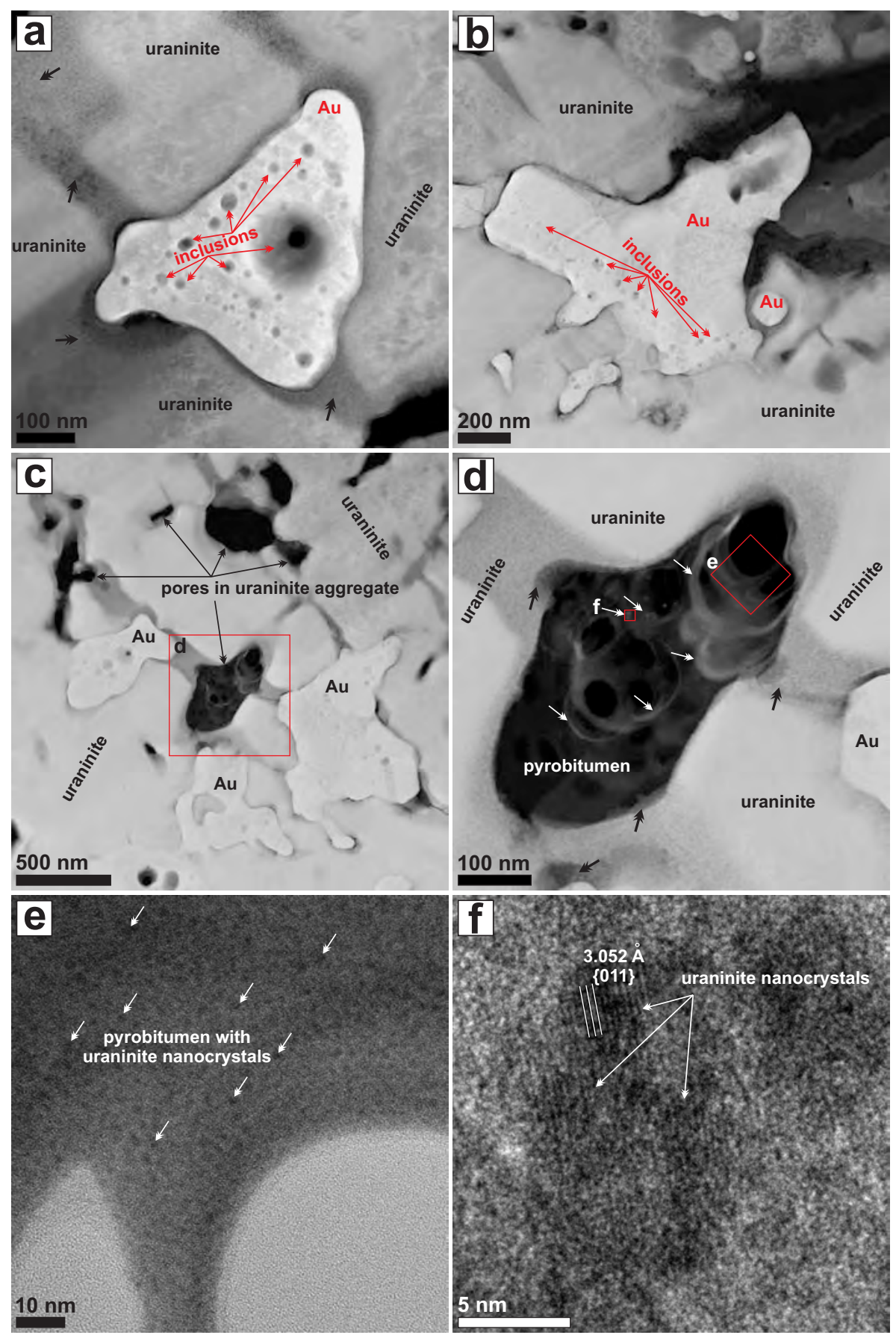

Figure 6 High-angle annular dark-field (HAADF) and bright-field TEM images of FIB foil 1. (a, b, c) Native gold filling pores in a uraninite aggregate. (d) Pore in the uraninite aggregate filled with pyrobitumen that contains white bands (white arrows). (e) Bright-field image of the pore-filling pyrobitumen in area "e" in (d). The white bands in the HAADF image of the pyrobitumen in (d) were caused by the presence of uraninite nanocrystals. (f) Lattice-fringe image of uraninite nanocrystals from area "f" in (d). Note: The network of uraninite nanocrystals can be recognized in less dense areas of the FIB close to pore spaces. The uraninite nanocrystals appear as small white or light grey dots in these areas (black arrows in (a) and (d)). 

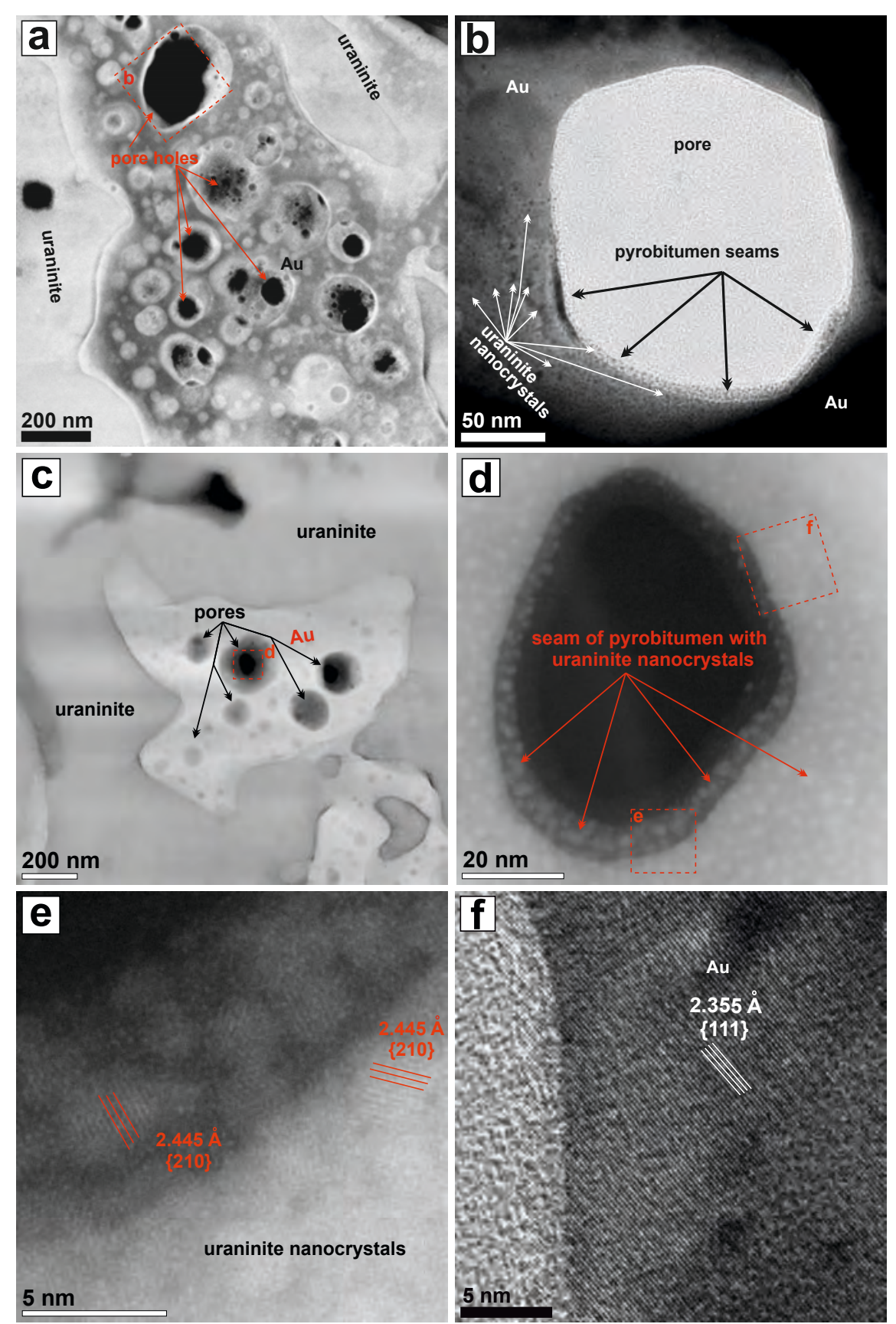

Figure 7 Native gold with numerous partly-filled pores in a uraninite aggregate. (a) HAADF image of the area indicated with "Fig. 7a" in Figure 4b. Some of the pores of the gold grain within the uraninite aggregate were intersected by the FIB foil surface and therefore appear as holes. (b) Bright-field TEM image of the pore labeled with "b" in (a). A thin film of pyrobitumen, which contains uraninite nanocrystals, covers the inner pore wall. (c) The HAADF TEM image of gold grains from FIB foil 1 that is indicated in Figure 4a. The numerous pores in the grains are marked with black arrows. (d) Enlargement of a pore in the gold grain labeled with "d" in (c) showing a thin pyrobitumen seam with uraninite nanocrystals lining the inner wall of the pore. In this HAADF TEM image, the pyrobitumen seam appears dark and the nanocrystals of uraninite bright. (e) High magnification image of uraninite nanocrystals in the area labeled " $e$ " in (d). The individual uraninite nanocrystals are identified by their $\{210\}$ families of lattice planes. (f) Bright-field TEM lattice-fringe image of the wall of the gold pore marked with " $\mathrm{f}$ " in $(\mathrm{d})$ showing the $\{111\}$ families of lattice planes of gold. The light grey area is the edge of a pore. 

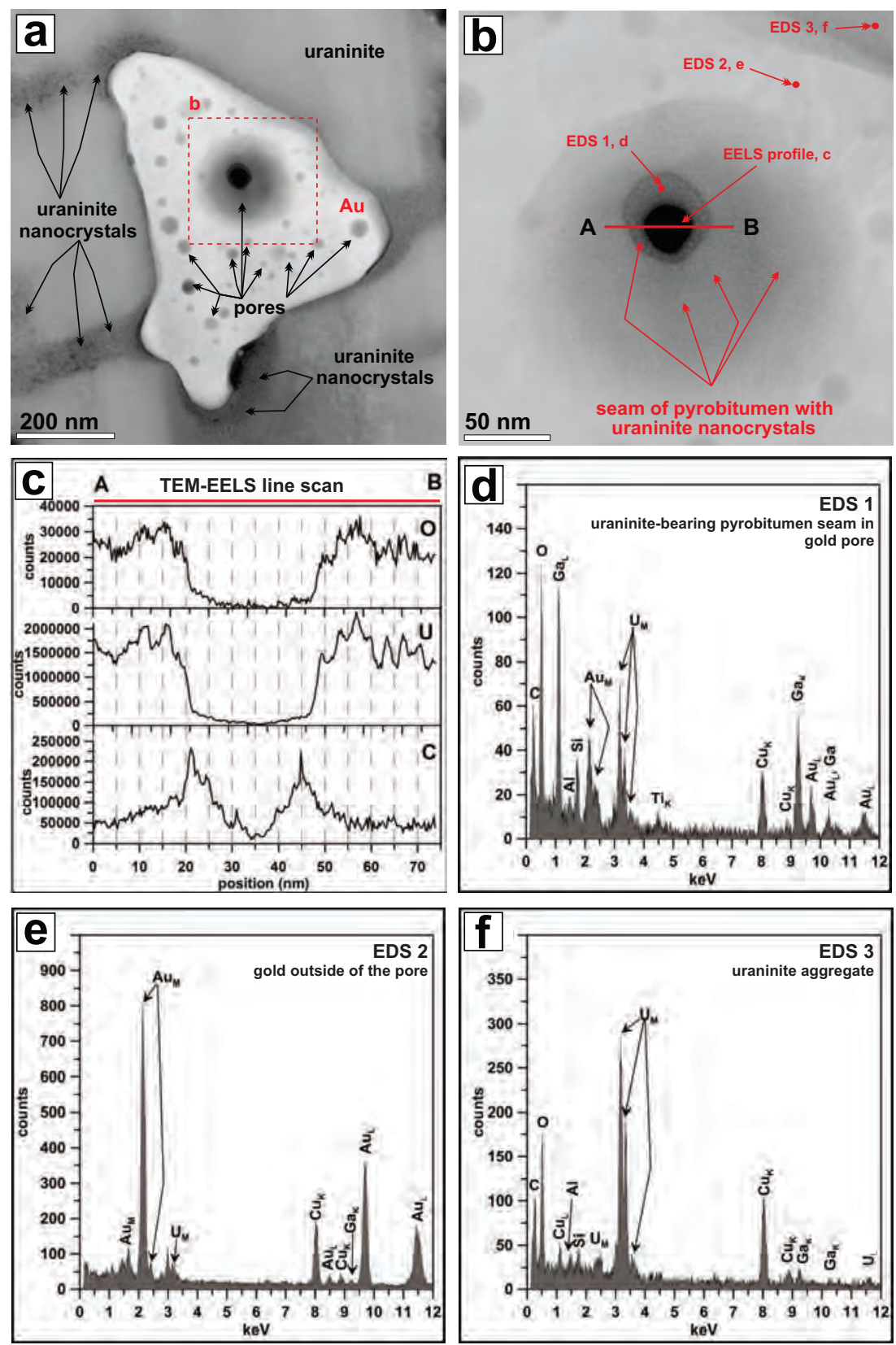

Figure 8 High-angle annular dark-field (HAADF) TEM images, TEM-based electron energy loss spectroscopy (EELS) profiles and EDS spot analyses on and across a uraninite nanocrystal- and pyrobitumen-bearing pore in a gold grain, the gold grain and the surrounding uraninite aggregate. (a) HAADF image of the studied gold grain that contains numerous pores and is located in the uraninite aggregate. (b) High magnification image of the area labeled " $b$ " in (a) showing the position of the EELS profile (red line) and the EDS spot analyses. The pore is partially filled by pyrobitumen and uraninite nanocrystals. The pyrobitumen seam appears in dark grey shades and the uraninite nanocrystals therein in bright grey shades. (c) EELS profiles for $\mathrm{C}, \mathrm{U}$ and $\mathrm{O}$ across the pore of the gold grain. The high $\mathrm{C}$ counts correspond to the inner part of the carbonaceous rim and the high $\mathrm{U}$ and $\mathrm{O}$ counts to uraninite nanocrystals in the central part of the rim. (d) EDS spot analyses of the pyrobitumen seam on the pore walls of the gold grain. (e) EDS spot analysis of the gold grain outside the pore. (f) EDS spot analysis of the uraninite aggregate hosting the gold grain. Note: The Ga peak is due to Ga incorporated in the specimen during the FIB foil preparation, and the $\mathrm{Cu}$ peak originates from the copper TEM grid on which the TEM specimen was mounted. 

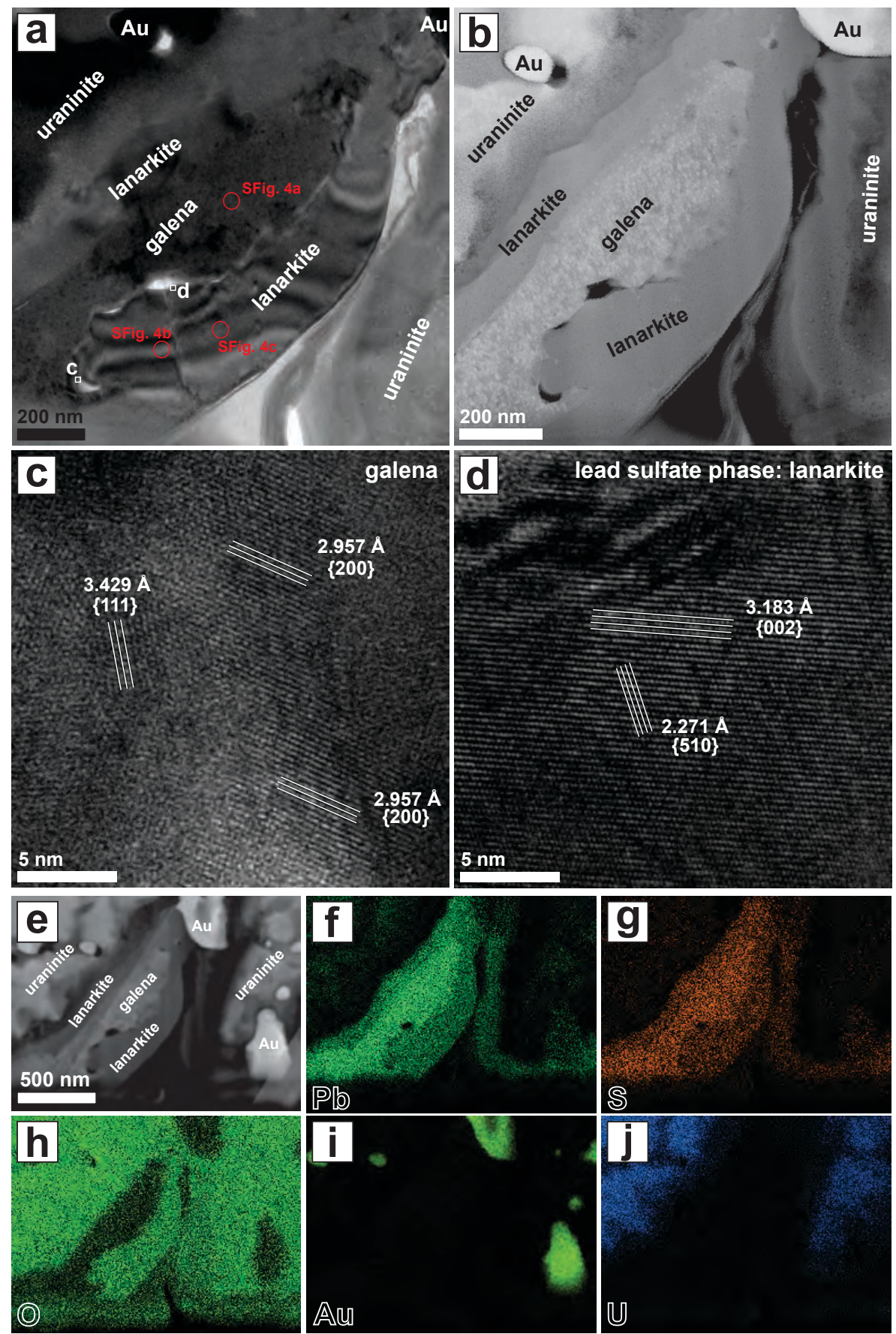

Figure 9 Bright-field and high-angle annular dark-field (HAADF) TEM images, and SEM-based element mapping of $\mathrm{Pb}$-bearing minerals in a uraninite aggregate. (a) Bright-field and (b) HAADF images of the area labeled "Fig. 9a" in Figure 4a. Galena is located in a large void in the uraninite aggregate and is completely surrounded by lanarkite. (c) Lattice-fringe image of area "c" in (a) showing the $\{111\}$ and $\{200\}$ lattice planes of galena. (d) Lattice-fringe image of area " $d$ " in (a) showing the $\{002\}$ and $\{510\}$ lattice planes of lanarkite. (e) HAADF image of the area labeled "Fig. 9e" in Figure 4a. (f, g, h, i, j) Scanning-electron microscope EDS element maps of the area in (e) showing the distribution of $\mathrm{Pb}, \mathrm{S}, \mathrm{O}, \mathrm{Au}$, and $\mathrm{U}$. 


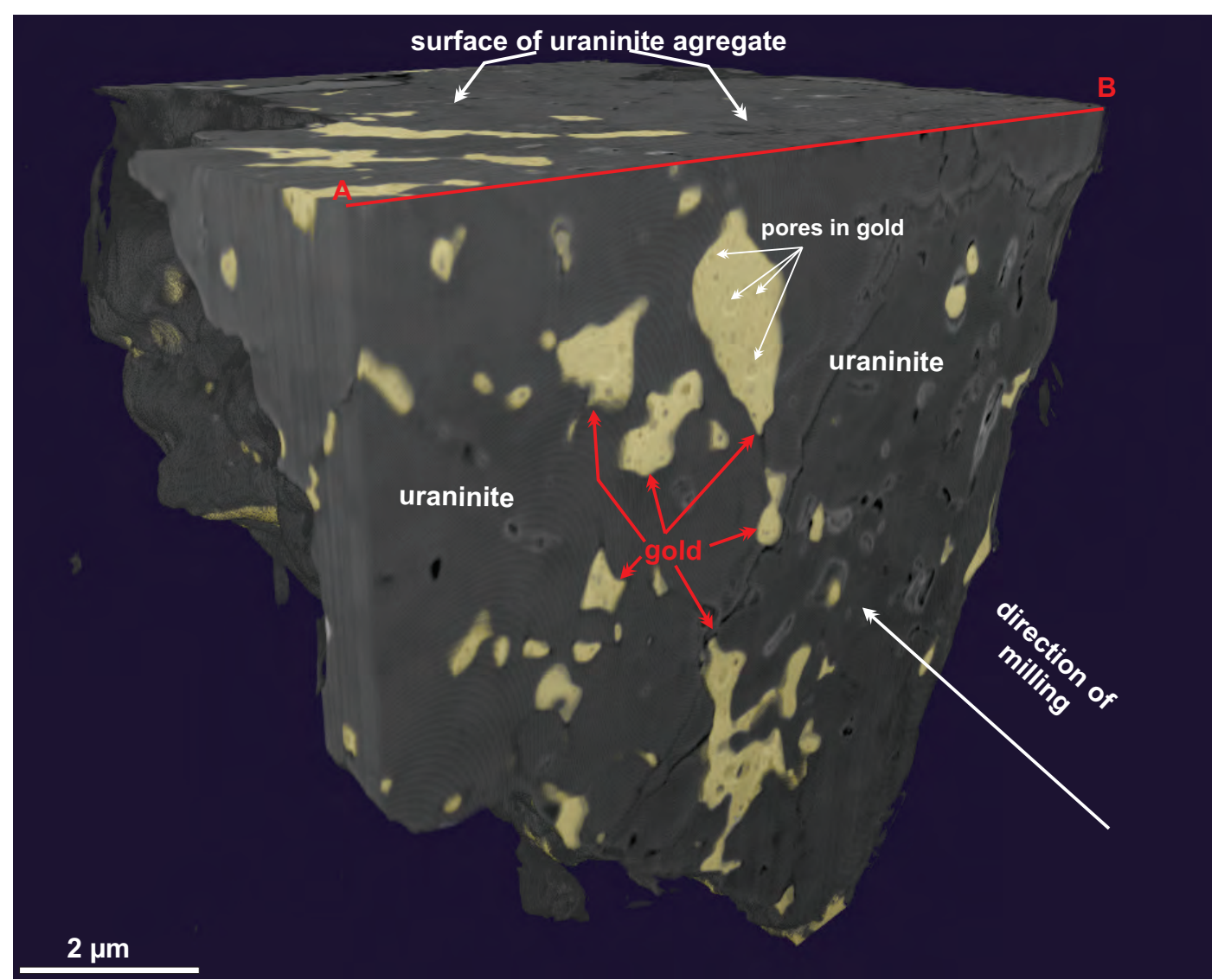

Figure 10 Still image of Video 1 showing the 3D nanotomography of a uraninite grain with gold in its pore spaces, which was acquired on a FIB SEM. For better visualization, uraninite and gold are overlain by grey and yellow false colors, respectively. 

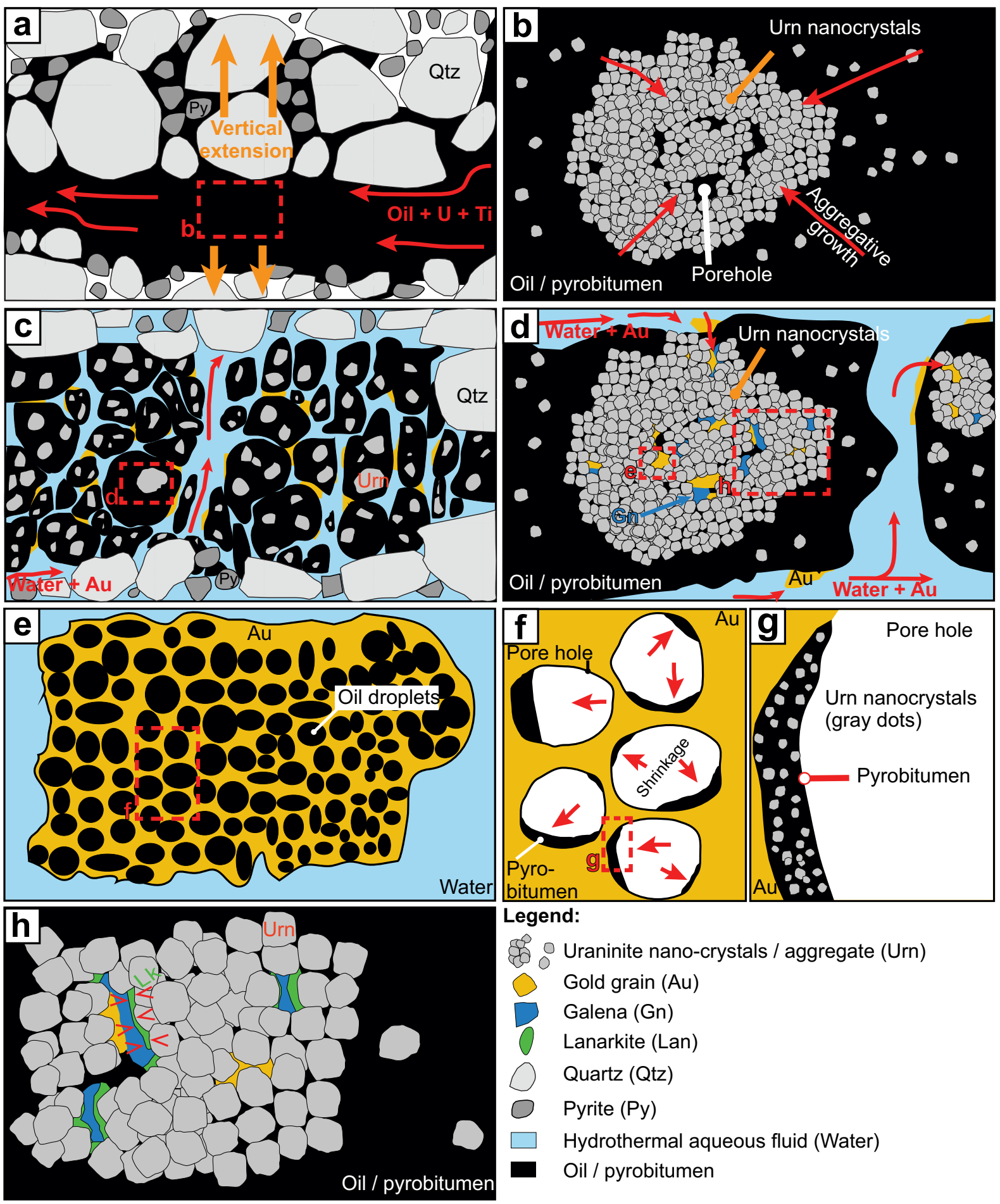

Legend:

\& U Uraninite nano-crystals / aggregate (Urn)

0 Gold grain $(\mathrm{Au})$

Galena (Gn)

0 Lanarkite (Lan)

$\bigcirc$ Quartz (Qtz)

0 Pyrite (Py)

$\square \quad$ Hydrothermal aqueous fluid (Water)

- Oil / pyrobitumen

Figure 11 Simplified sketch of the "emulsion model" showing the sequential precipitation of uraninite, native gold and associated minerals in the Carbon Leader Reef from a water-oil micro-emulsion. (a) Infiltration of (U + $\mathrm{Ti}$ ) - bearing liquid hydrocarbons into the sediment and vertical extension / dislocation of the corresponding detrital components. (b) Enlargement of the area labeled " $b$ " in image (a) showing the crystallization of uraninite crystals and the growth of uraninite nanocrystal aggregates by oriented attachment. (c) Invasion of gold-bearing, hydrothermal fluids, forming a micro-emulsion with the immiscible oil phase. (d) Deposition of gold on the walls of the hydrocarbon nodules and in the pores in the uraninite aggregates due to the reduction in $f \mathrm{O}_{2}$. (e) Enlargement of the area labeled " $\mathrm{e}$ " in image $(\mathrm{d})$ showing gold precipitated owing to the reduction against the enclosing oil droplets. (f) Enlargement of the oil-filled pores in the gold grain in (e) illustrating the thermal 
alteration of the hydrocarbons accompanied by their shrinkage against the pore walls. (g) Uraninite nanocrystals growing in the hydrocarbon films on the pore wall in the area marked "g" in (f). (h) Enlargement of the area labeled " $\mathrm{h}$ " in (d), showing the formation of galena and lanarkite in the pores spaces of the uraninite aggregate. Video file caption

\section{Videos}

Video 13 D nanotomography movie created from SEM InLens image stacks of a uraninite nanocrystal aggregate containing native gold in its pore spaces that, in turn, contains pyrobitumen at the pore walls. The video shows the internal structure and reconstructed volume of the uraninite aggregate and the gold grains therein. For better visualization, uraninite and gold are overlain by grey and yellow false colors, respectively. 


\section{Supplemental data}
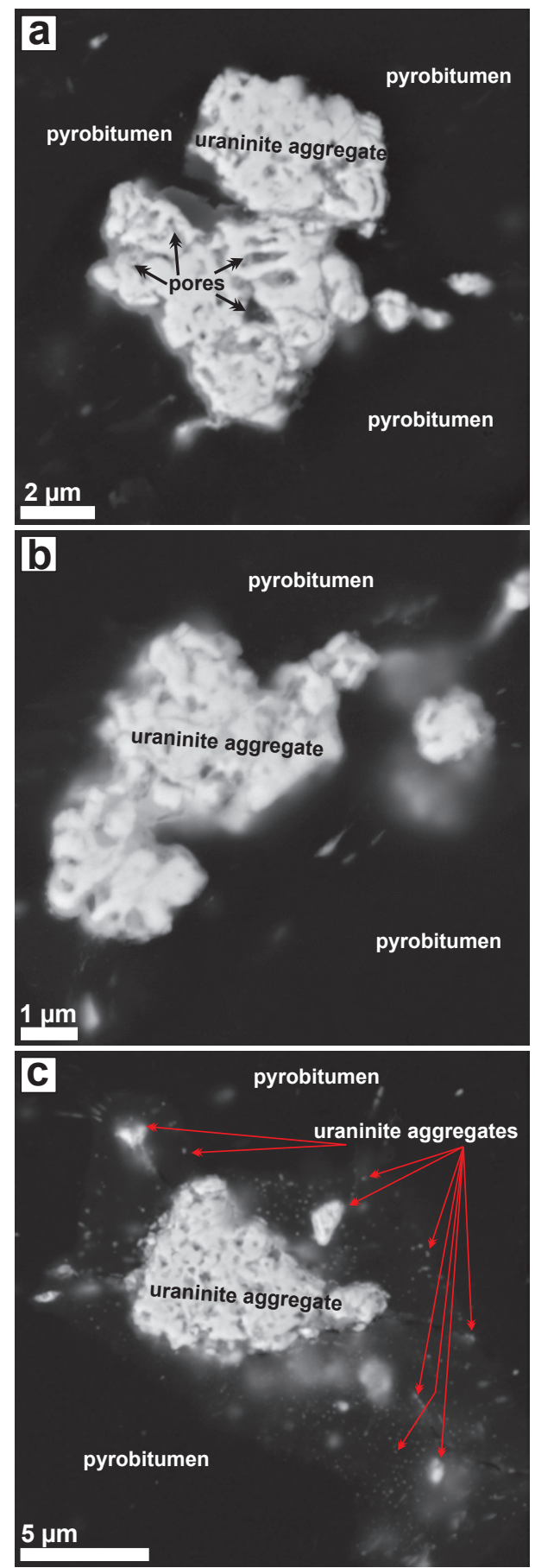

SFigure 1 Backscattered electron SEM images extracted from the ZEISS Atlas 5 large area image mosaic. (a, b, c) Small, irregularly-shaped uraninite aggregates in pyrobitumen nodules. Their locations are shown in Figure $3 c$. 


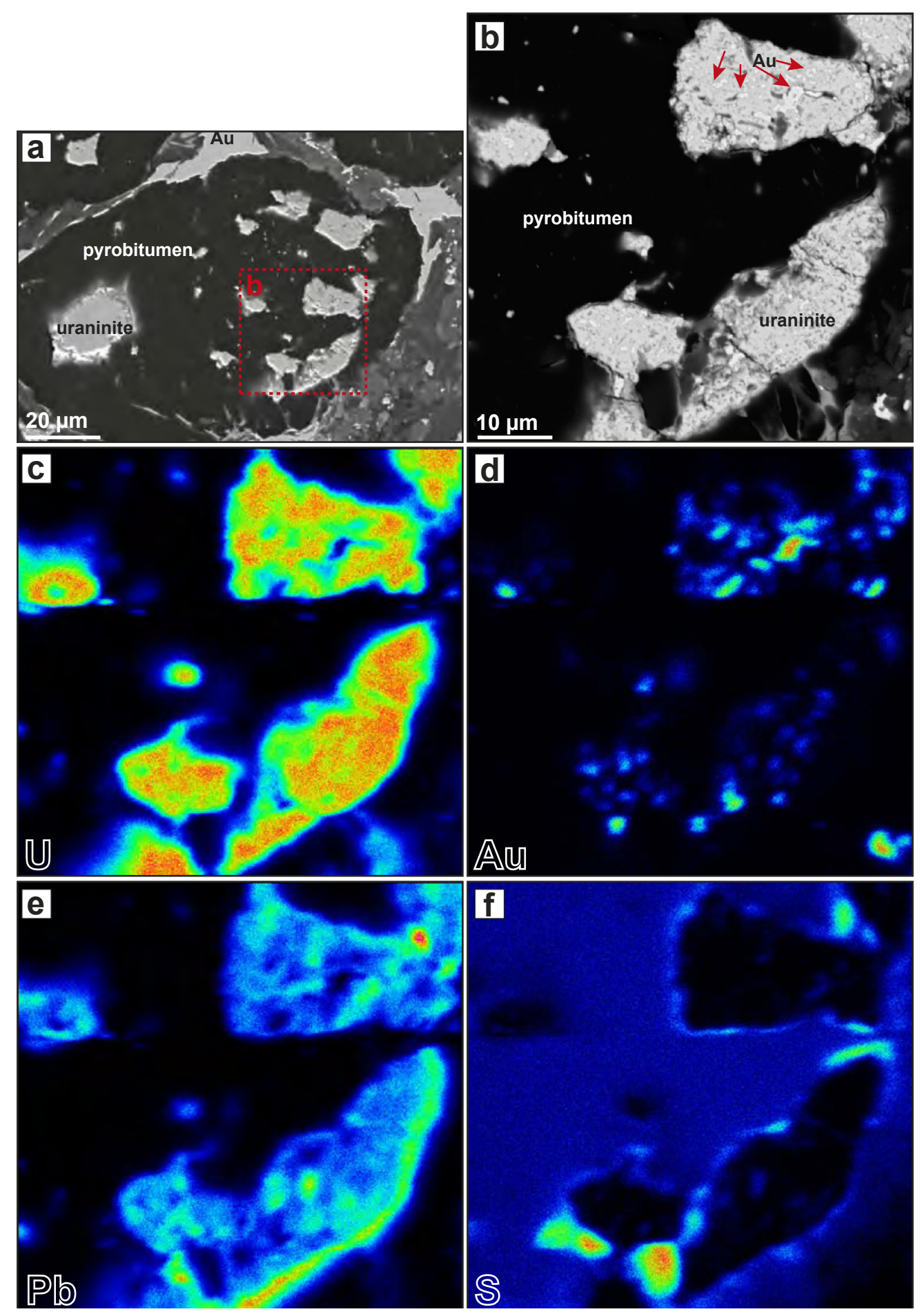

SFigure 2 (a, b) Backscattered electron SEM images showing the locations of the uraninite aggregates mapped with the EPMA. (c, d, e, f) EPMA-based element distribution maps of area "b" in (a) showing the distribution of $\mathrm{U}, \mathrm{Au}, \mathrm{Pb}$, and $\mathrm{S}$. 


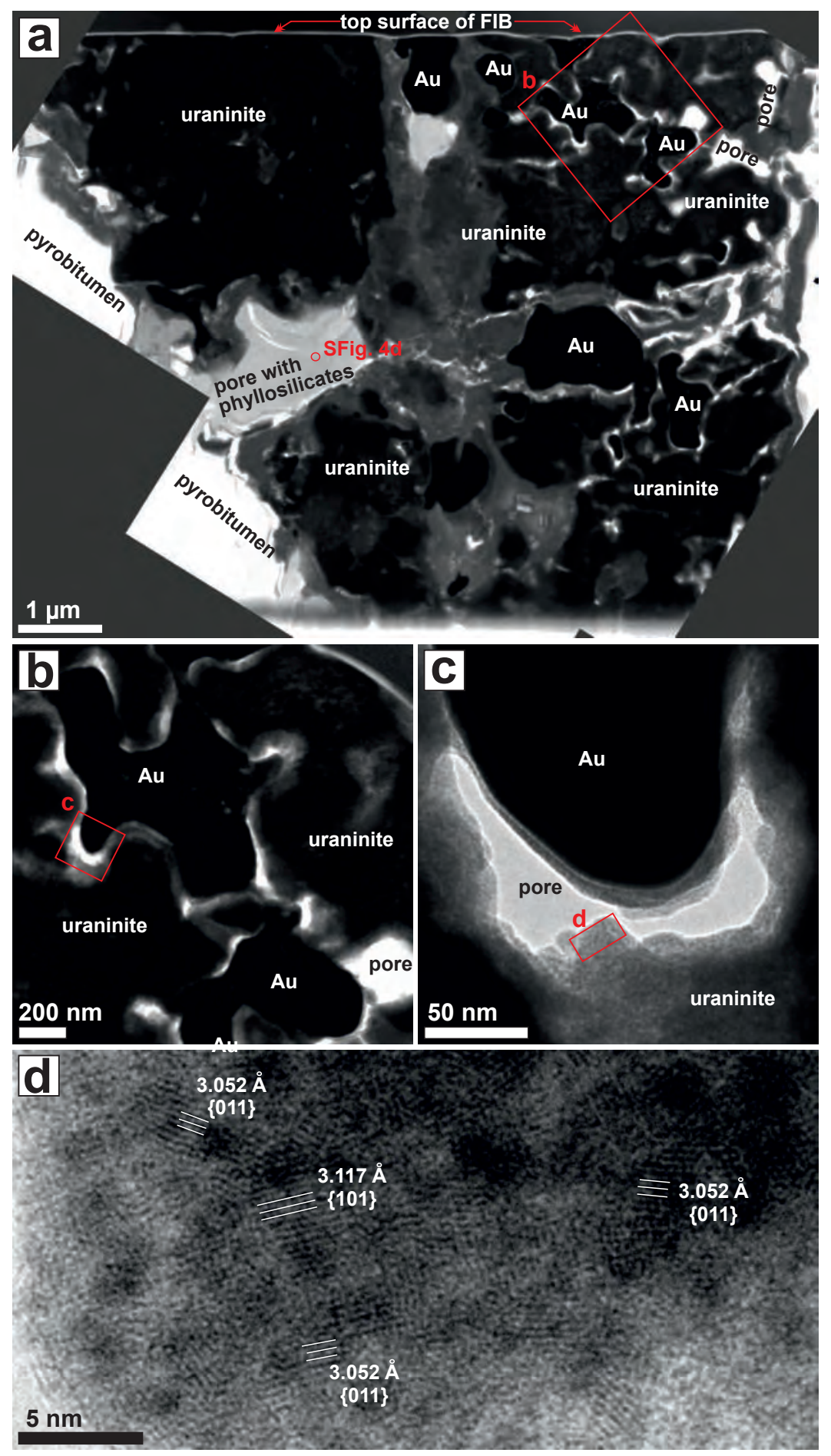

SFigure 3 Bright-field TEM images of FIB foil 2. (a) Bright-field TEM image mosaic of FIB foil 2 revealing the extremely porous nature of the uraninite aggregates. Several of these pores are filled with native gold and phyllosilicates. (b) Pores in the uraninite aggregate that are filled with native gold. (c) Enlargement of area "c" in (b) showing gold surrounded by uraninite. (d) Lattice-fringe image of area " $\mathrm{d}$ " in (c) revealing an aggregate of nanocrystals displaying the $\{011\}$ and $\{101\}$ families of lattice planes of uraninite. 

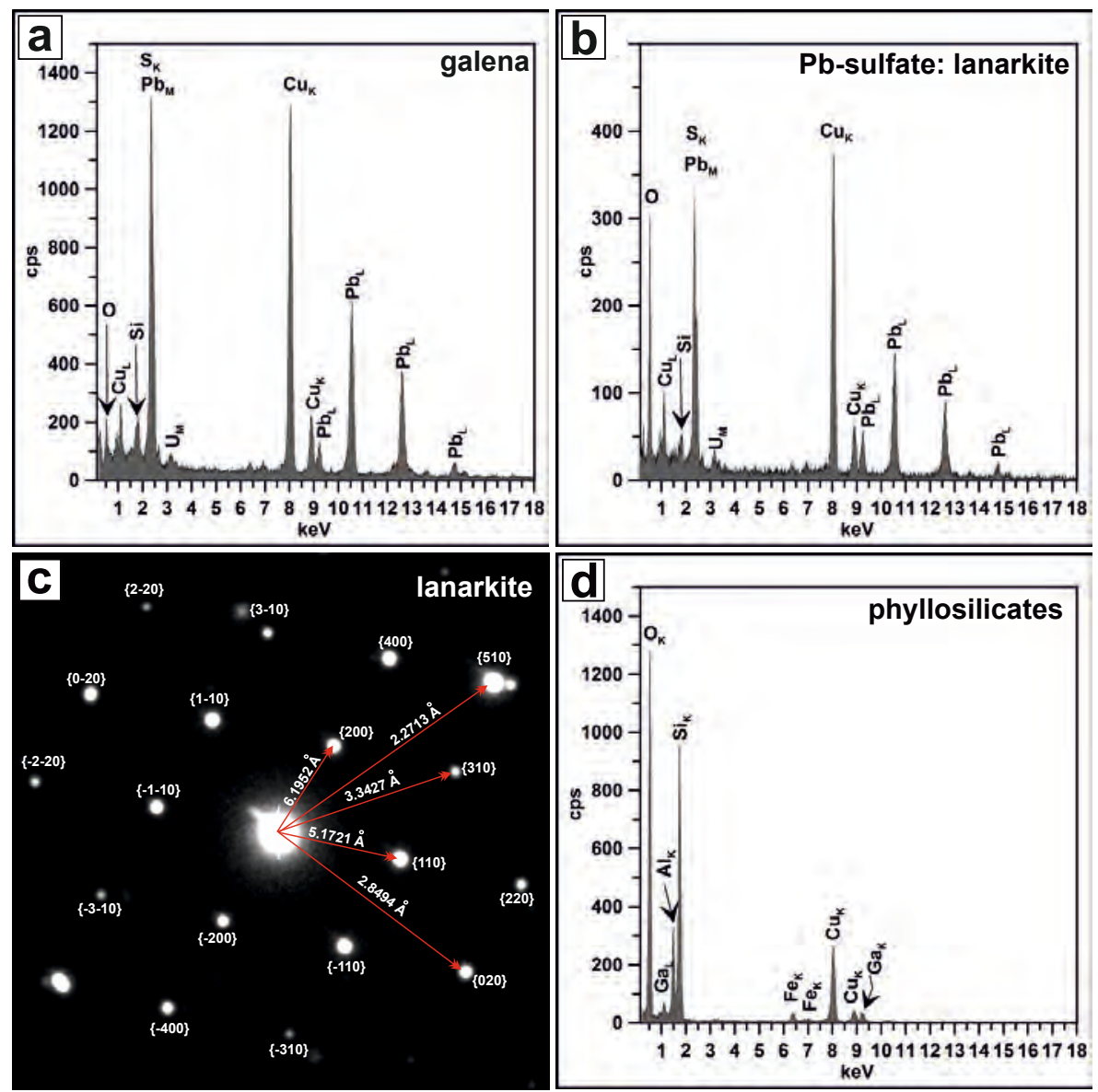

SFigure 4 TEM-based EDS point analyses and electron diffraction pattern as indicated in Figure 9a and SFigure 3. (a, b) Point analysis of galena and lanarkite. (c) Electron-diffraction pattern for the lanarkite. (d) Point analysis of the pore-filling phyllosilicates marked in SFigure 3a. 

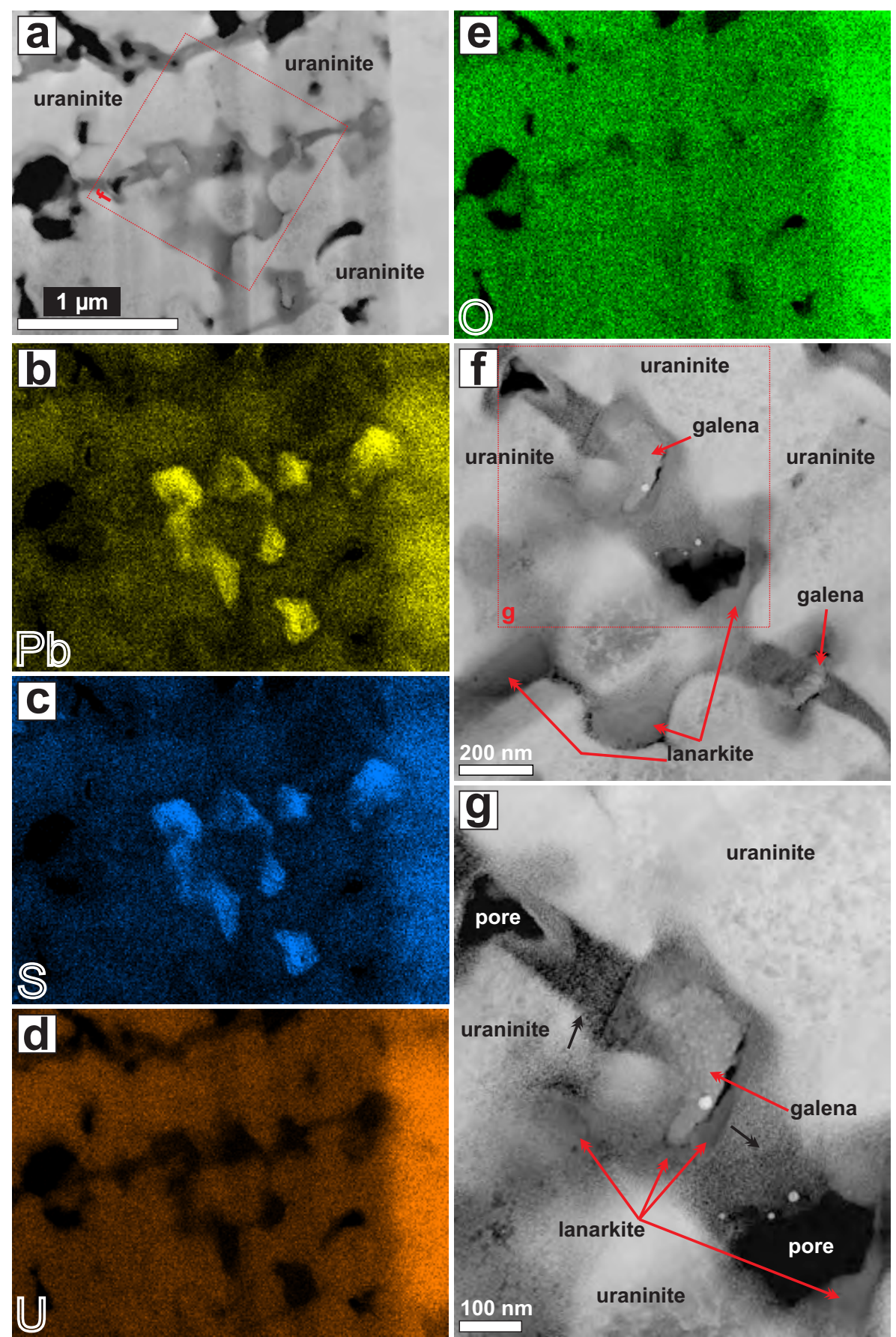

SFigure 5 (a) HAADF image of an area labeled with "SFig. 5a" in Figure 4a showing a uraninite aggregate containing pores filled with galena and lanarkite. (b, c, d, e) SEM-based EDS element maps corresponding to image (a) showing the distribution of $\mathrm{Pb}, \mathrm{S}, \mathrm{U}$, and $\mathrm{O}$. (f) An enlargement of area " $\mathrm{f}$ " in (a) showing the uraninite aggregate together with galena and lanarkite in the pores. (g) An enlargement of area "g" in (f) showing the relationship of the lanarkite to the galena. The galena is completely surrounded and replaced by lanarkite, which fills the remaining pore space. 


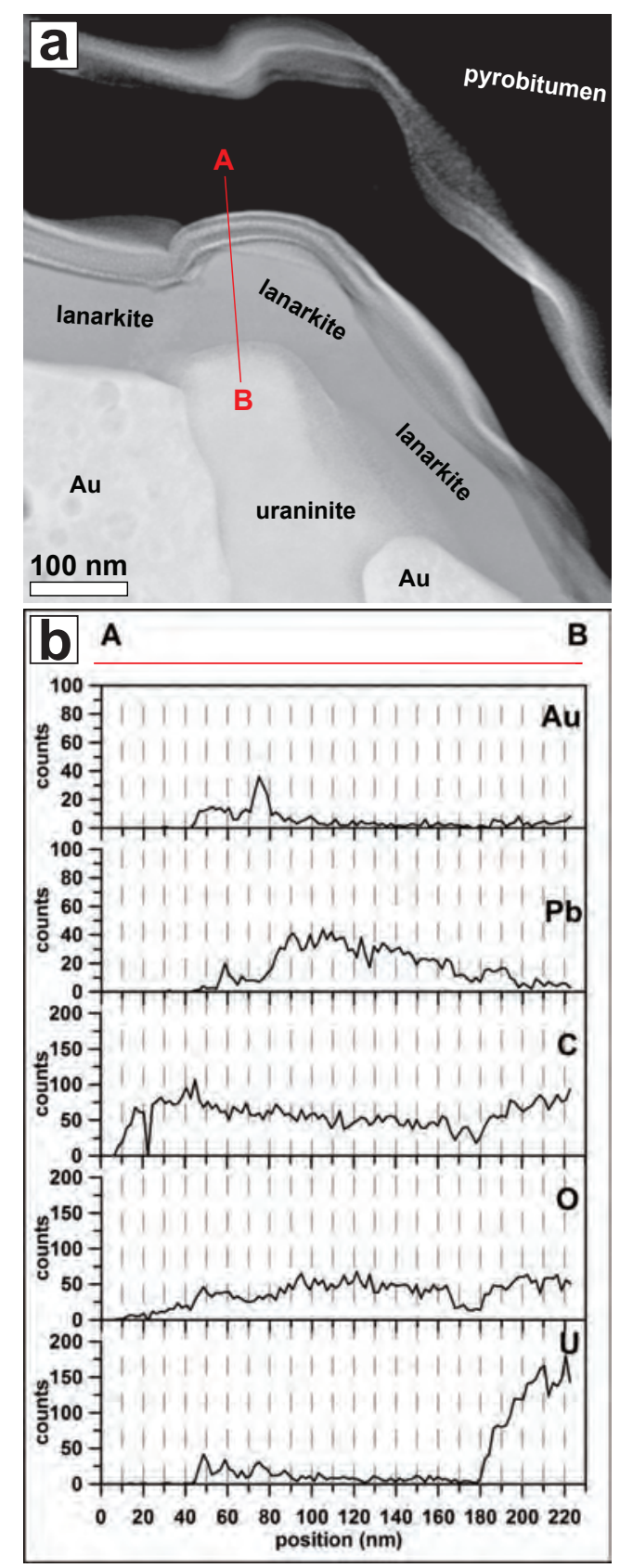

SFigure 6 (a) HAADF image of the area labeled with "SFig. 6a" in Fig. 4b showing gold, uraninite and lanarkite at the interface with pyrobitumen. (b) TEM-EDS line scan across the lanarkite rim showing increased counts for $\mathrm{Au}, \mathrm{Pb}, \mathrm{C}, \mathrm{O}$ and $\mathrm{U}$ (line $\mathrm{A}-\mathrm{B}$ in (a)). 

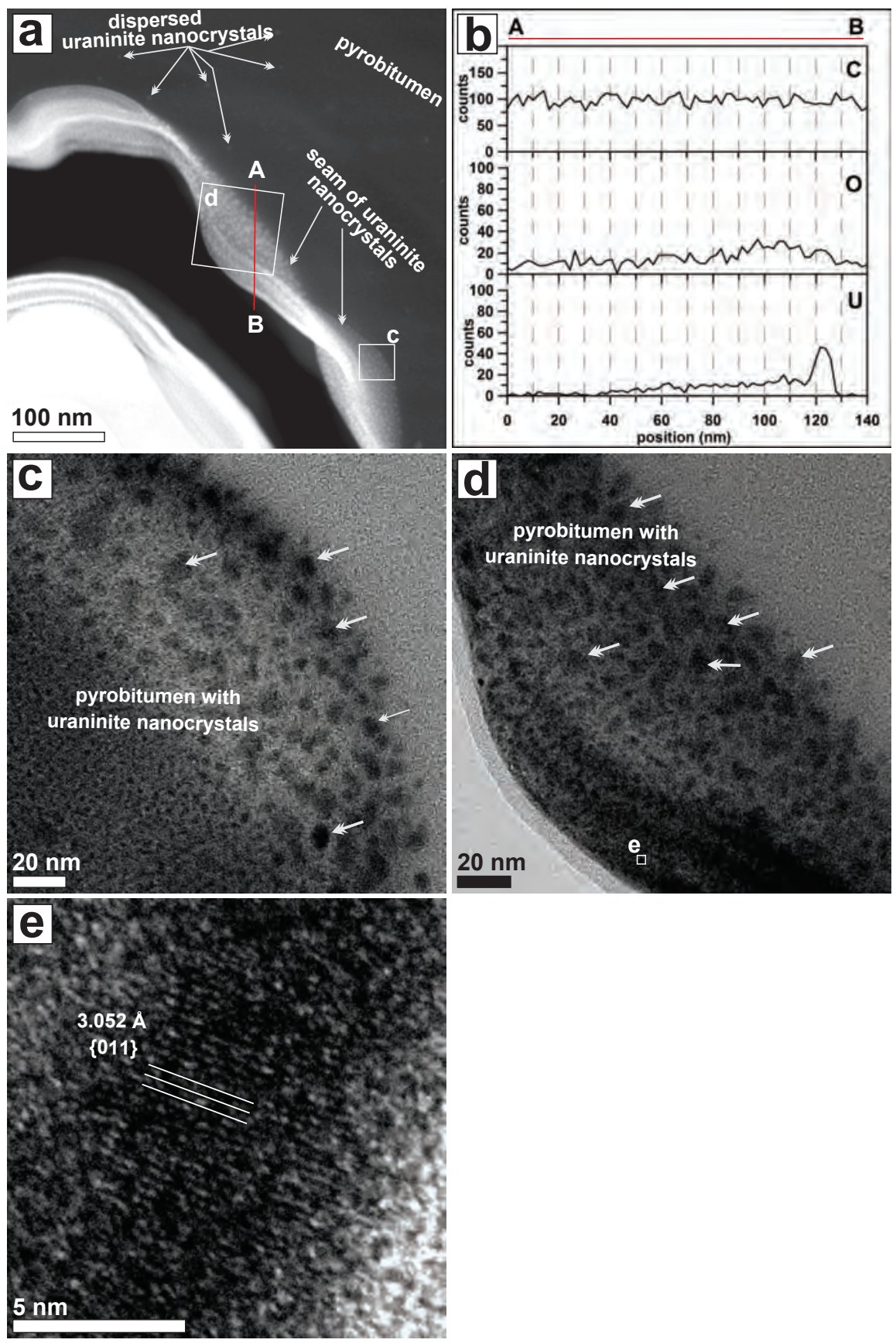

SFigure 7 (a) HAADF image of the area labeled with "SFig. 7a" in Fig. 4b showing the boundary between a pyrobitumen nodule and a uraninite aggregate. Note: The pyrobitumen was separated from the uraninite aggregate during the FIB milling. The pyrobitumen close to the uraninite is enriched in uraninite nanocrystals. (b) TEM-EDS line scan along A - B in (a) showing counts for the elements C, O, and U. (c, d) Bright-field TEM images of areas " $c$ " and " $d$ " in (a) showing uraninite nanocrystals. (e) Lattice-fringe image of a uraninite nanocrystal showing the $\{011\}$ lattice planes. 